DIW BERLIN

Discussion Papers

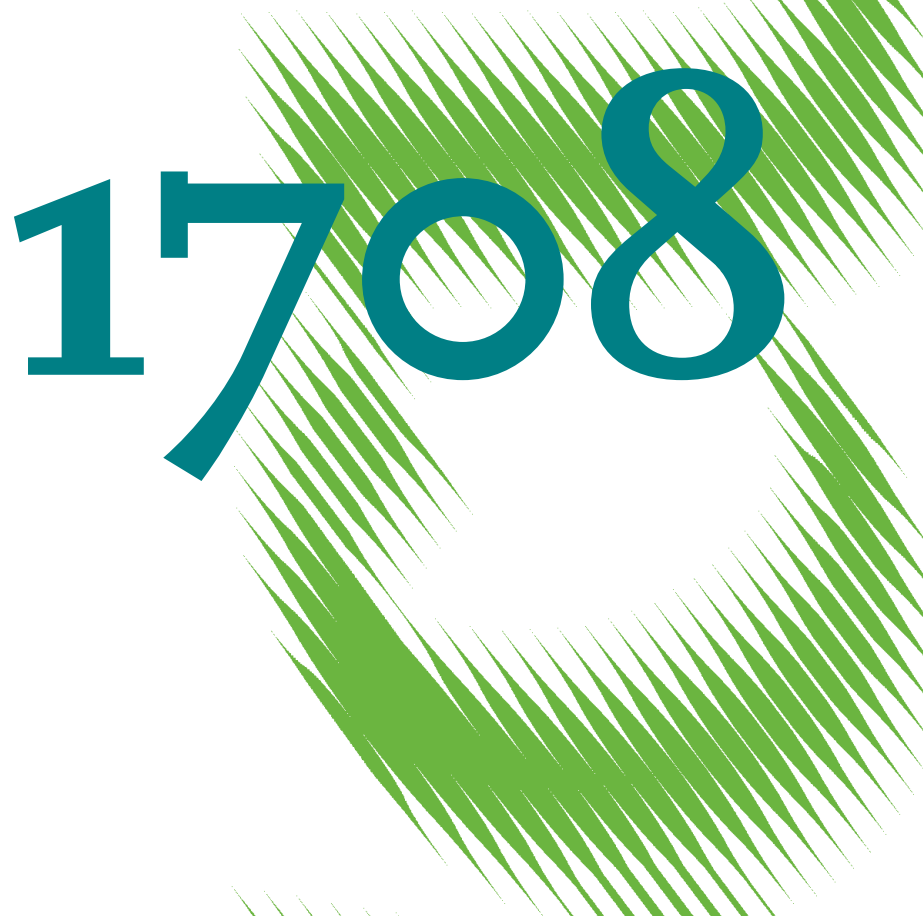

Entitled Women - but Not Men Make Tougher Strategic Demands as Proposers in the Ultimatum Game 
Opinions expressed in this paper are those of the author(s) and do not necessarily reflect views of the institute.

IMPRESSUM

(C) DIW Berlin, 2017

DIW Berlin

German Institute for Economic Research

Mohrenstr. 58

10117 Berlin

Tel. +49 (30) $89789-0$

Fax +49 (30) $89789-200$

http://www.diw.de

ISSN electronic edition 1619-4535

Papers can be downloaded free of charge from the DIW Berlin website:

http://www.diw.de/discussionpapers

Discussion Papers of DIW Berlin are indexed in RePEc and SSRN:

http://ideas.repec.org/s/diw/diwwpp.html

http://www.ssrn.com/link/DIW-Berlin-German-Inst-Econ-Res.html 


\title{
Entitled Women - but Not Men - Make Tougher Strategic Demands as Proposers in the Ultimatum Game
}

\author{
Elif E. Demiral ${ }^{*}$ \\ Johanna Mollerstrom $^{\dagger}$
}

December 2017

Newer version published at DP 1756 (2018); Please cite the new version

\begin{abstract}
:
In a laboratory experiment subjects are matched in pairs and interact in an Ultimatum Game. In the Entitlement treatment, the right to be the proposer is allocated to the person in the pair who performed better in a previously conducted math task. Compared to behavior in the control treatment, where the roles are randomly allocated, the proposers increase their strategic demands and offer a smaller share of the pie to the responder in the Entitlement treatment. This result is driven entirely by female proposers; when earning their role, they significantly lower their offers, whereas male proposers do not behave differently than when roles are randomly allocated. This is in line with previous research suggesting that women are more sensitive to contextual factors and social cues, meaning that strengthening feelings of entitlement could be a way to decrease gender differences in negotiation behavior.
\end{abstract}

\footnotetext{
* Interdisciplinary Center for Economic Science, George Mason University, 4400 University Dr, Fairfax, VA 22030, USA. E-mail: edemiral@gmu.edu. Corresponding author.

${ }^{\dagger}$ Humboldt University, DIW Berlin, and Research Institute for Industrial Economics (IFN), Mohrenstr. 58, 10115 Berlin, Germany. E-mail: johanna.mollerstrom@gmail.com.

We thank Dan Houser, Cesar Martinelli, Kevin McCabe and the participants in the workshop on Public Choice Experiments at Universite Catholique de Lille for fruitful interactions about this work, and we are grateful to excellent comments on previous versions of the manuscript from Coren Apicella, Katie B. Coffman, Christine Exley and Elizabeth Hoffman. We gratefully acknowledge funding for the experiment from the Interdisciplinary Center for Economic Science at George Mason University.
} 


\section{Introduction}

To better understand the persistent gender gaps in society, especially in labor market outcomes, researchers are investigating negotiation behavior. Laboratory and field experiments document that women are both less willing to enter negotiations in the first place and that they bargain less aggressively than men when actively negotiating (e.g. Babcock and Laschever, 2003). One possible reason that has been suggested for why this gender gap in negotiations is observed is that women may take less credit for their success (c.f. Deaux and Farris, 1977; Apicella et al., 2017), and feel less entitled to higher pay than men (Major et al., 1984; Barron, 2003; Gelfand and Stayn, 2012.; for a review, see Gelfand and Stayn, 2012). If this is the case, one potentially fruitful way to encourage tougher behavior in negotiations by women would be to strengthen their feelings of entitlement.

However, manipulating feelings of entitlement for women only, without also making men feel more entitled, may be difficult in many real world settings. We investigate a way to get around this, using the experimental literature's finding that women are more sensitive to contextual factors and social cues than men (Croson and Gneezy, 2009) as a starting point. For example, the fact that subjects cooperate more when a Prisoners' Dilemma is labeled as a "Community Game” as opposed to a "Stock Market Game” has been shown to exclusively originate from women changing their behavior between the frames (Ellingsen et al., 2013).

In our laboratory experiment, we use a design similar to Hoffman et al. (1994) to investigate the impact of increased feelings of entitlement on behavior in an Ultimatum Game (UG). We use two treatments: In the Entitlement treatment, proposers are chosen based on superior performance in a previously conducted task. In the Random treatment, 
the roles of proposer and responder are randomly allocated in the pair. We replicate the result from Hoffman et al. (1994) that proposers, on average, are tougher in their strategic demands in the sense that they offer a smaller share to their matched responder in the Entitlement treatment. We further show that there are significant differences in how men and women react to earned entitlements, documenting that the average reaction to treatment is driven entirely by the female proposers. ${ }^{1}$ When women earn the right to be the proposer in the UG, they respond by claiming a significantly larger share for themselves compared to the Random treatment, whereas male proposers do not change their behavior. In our setting, this implies that whereas there is no gender difference in offers in the Random treatment, women actually make tougher strategic demands than men in the Entitlement treatment.

Our work is related to several strands of literature. First, the research on gender differences in negotiation behavior is extensive (c.f. Babcock and Laschever, 2003). The results from research studying gender differences in how proposers make strategic demands in the UG are mixed, with some documenting that women claim less for themselves and others finding that there is no gender difference (Eckel and Grossman, 2001; Solnick, 2001). Other experimental work frames the interactions as a (sometimes hypothetical, sometimes real) wage negotiation, resulting in more clear cut findings, with female subjects found to set lower goals, state lower minimum acceptable wages, and negotiate lower compensation than men (see e.g. Stevens et al., 1993; Kaman and Hartel, 1994; Dittrich et al., 2014 and Exley et al., 2017). Moreover, the context of the negotiation matters: providing information on others’ negotiation decisions (Rigdon, 2012) and framing the

\footnotetext{
${ }^{1}$ Hoffman et al. (1994) utilize a double blind procedure that does not allow for the collection of data on participants’ gender.
} 
negotiation as an ask rather than a negotiation (Small et al., 2007) both help to close the gender gap in negotiation.

Research using field data also point in the direction of women negotiating less often and less successfully. For example, Babcock et al. (2003) document that recent female MBA graduates negotiate for their starting salaries significantly less often than their fellow male graduates. This contributes to the fact that women earn less than men, even when graduating from the same MBA program. Leibbrant and List (2014) show that women are more likely to signal to employers that they are willing to accept a lower wage than what is advertised and that the context matters: explicitly informing prospective employees about what is negotiable reduces the gender gap in willingness to negotiate.

The second strand of literature we build upon is the one aiming at understanding the effects of entitlements on behavior in not only the UG but also in other games, such as the Dictator Game (DG). Hoffman et al. (1994) was of the first to ask the question of how behavior differs between earned and randomly allocated endowments in the UG and DG. Their findings, that proposers offer less of their endowment to the responder in the UG and to the receiver in the DG when they have earned the right to be the proposer, has been widely replicated and extended (e.g. Cherry, 2001; Cherry et al., 2002; Oxoby and Spraggon, 2008; Banerjee and Chakravarty, 2014; Korenok et al., 2017; see also Hoffman and Spitzer, 1985, which partly foreruns the work in Hoffman et al., 1994). To our knowledge however, the existing literature does not investigate gender differences. Thus we are the first to suggest, and find evidence for, the well-established finding of the effects of entitlements on proposer behavior in the UG may be driven by women. 
From here, the paper proceeds as follows. We start by describing the experimental design and implementation in Section 2. In Section 3, we conduct the analysis, document our main findings and discuss potential mechanisms. Section 4 concludes.

\section{The Experiment}

\subsection{Experimental Design}

The experiment consisted of three parts. In the first part, all participants completed an arithmetic task. ${ }^{2}$ They had five minutes in which to provide the answers to a series of math tasks that consisted of adding up five two-digit numbers (c.f. Niederle and Vesterlund, 2007). Participants were informed that they would receive $\$ 0.25$ for each correct answer, that they would be paid at the end of the experiment, but that prior to the payout, no information about own performance would be given. Subjects never learned the details about others' performance.

Ahead of the second part of the experiment, participants were matched in pairs. Our experiment entailed two treatments. In the Random treatment, one of the participants in the pair was randomly given the right to be the proposer in the game that followed. In the Entitlement treatment, this right was awarded to the person in the pair who performed better in the math task in the first part (ties were broken randomly by the computer). In both treatments, participants were informed whether the proposer (neutrally labeled "Player A" and described as the more advantageous position) and responder (labeled "Player B”) roles were allocated randomly or based on performance.

\footnotetext{
${ }^{2}$ All instructions and questionnaires are available in the Online Appendix.
} 
In order to ensure that the selected proposers and responders, respectively, were comparable in characteristics between the treatments, pairing was done in the following way. Immediately after the first part, subjects were ranked from highest to lowest according to their performance in the math task. The subject ranked first was then matched with the subject ranked second, the subject ranked third was matched with the subject ranked fourth, and so on. The subjects were told that they were matched anonymously to another person in the room; we took care to not claim that the match was random.

In the second part of the experiment, participants played a one-shot UG. The proposers offered a division of a total endowment of $\$ 20$ between themselves and their matched responder. For the responders we used the strategy method, and they stated a minimum acceptable division of the pie, i.e. how large their share would have to be for them to accept the offer. They were informed that if the minimum acceptable offer was less than or equal to the actual offer made by the matched proposer, the money would be split as proposed and paid out at the end of the experiment. If the minimum acceptable offer exceeded the offer made, both participants in the pair would receive nothing.

The third part of the experiment consisted of a belief elicitation stage. Proposers were asked to predict the minimum acceptable offer that the matched responder had indicated, and similarly the responders were asked to state their beliefs about the offer that their matched proposer had actually given. Participants were also asked to predict the number of correct math tasks done both by themselves and by the other people in the room. For all belief elicitations, participants were informed that they would be rewarded based on the accuracy of their estimates and that a more accurate belief would yield a higher payoff (for details, see the instructions in the Online Appendix). 
After the experiment was concluded, participants were informed about their payoffs. Before the earnings were privately paid out, participants completed a questionnaire collecting demographic information. We also asked questions regarding risk preferences, fairness views, and feelings of deservingness.

\subsection{Design deviations from Hoffman et al. (1994)}

As our objective is to test if the results presented in Hoffman et al. (1994) are driven by women's behavior, it is natural that our design closely reflect theirs. However, we consciously made a few deviations from their design. First, in order to be able to study gender differences we did not implement a double blind design, but did collect demographic information and matched it to the participants' behavior in the experiment.

Second, while Hoffman et al. use a general knowledge quiz in the first part of the experiment we use a math task. The reason is that we know from previous experiments that performance in this task tend to be gender neutral in this particular student population. Third, Hoffman et al. implemented the quiz in part one only in their Entitlement treatment but not in their Random treatment. In order to increase comparability between treatments we chose to implement the math task in both treatments.

Fourth, we used the strategy method for the responders in that we asked them to report minimum acceptable offers as opposed to simply asking them to accept or reject the offer actually extended to them by their matched responder. We did this in order to collect richer information on responder behavior and to be able to elicit more precice beliefs from the proposers about the behavior of their matched respondents. The fact that we use the strategy method for the responders does not, however, impact how the instructions to the 
proposers are put before they make their decision on offers, and hence our design remains comparable to that of Hoffman et al. regarding proposer behavior.

The final, and most important, difference between our design and Hoffman et al. is the pairing mechanism described above. We implemented this in order to ensure that the math ability (and characteristics potentially correlated with this), and earnings from part 1, are held as constant as possible between proposers and responders, respectively, in the two treatments. Hoffman et al. on the other hand also rank their participants according to ability, but give the proposer roles to the 50 percent of participants who performed better thereby increasing the likelihood that proposers differ more in performance compared to the responders in the Entitlement treatment than in the Random treatment.

\subsection{Implementation}

The instructions were provided immediately ahead of each part, both on participants' screens and read aloud by the experimenter, thus ensuring common knowledge. Between the first and the second part, participants took part in a quiz to ensure that they had understood the instructions and procedures. Those (very few) participants who had problems answering the quiz were given a repetition of the instructions by the experimenter.

An even number of subjects participated in each of the ten experimental sessions. No communication was allowed among participants and matching was done anonymously. The experiment (programmed with z-Tree, Fischbacher, 2007) was conducted at the 
Interdisciplinary Center for Economic Science (ICES) Laboratory at George Mason University in February 2016, with 128 undergraduate students participating. The treatments were randomly allocated at the session level (five Random and five Entitlement sessions). Participants earned an average of $\$ 18.40$ (including a fixed show-up fee) for their participation in a session that lasted approximately 40 minutes. Although we recruited an equal number of men and women to each session, we had 66 women and 62 men participating; this small deviation from 50/50 is the result of a slight gender difference in showup rates.

\section{Results}

\subsection{Proposer Behavior}

Figure 1 displays the behavior of the participants chosen as the proposers in the Entitlement treatment (panel A) and the Random treatment (panel B). In the point estimates, we replicate the findings from Hoffman et al. (1994) and observe that whereas the proposers on average offer $\$ 8.29$ out of the $\$ 20$ pie to the matched responders in the Random treatment, this sinks by 11 percent to $\$ 7.36$ in the Entitlement treatment ( $\mathrm{p}=0.050$ with the Wilcoxon-Mann-Whitney (WMW) test and $\mathrm{p}=0.155$ with Wald test $^{3}$ ).

\footnotetext{
${ }^{3}$ All tests are two-sided and all Wald tests use robust standard errors. Unless otherwise noted the Wald tests in this and the next section control for 1) performance in the first part of the experiment, and 2) risk aversion. The reason for 1) is that even though the pairing mechanism in our design gets us very close to random assignment of the proposer role also in the Entitlement treatment, there will most likely still be a residual difference with proposers in the Entitlement treatment having on average higher performance in the math task than the proposers in the Random treatment. We indeed observe such a difference in the point estimates: in the Random treatment, proposers and responders had average scores of 7.52 and 7.32 respectively. In the Entitlement treatment, the corresponding figures were 7.97 and 7.24. Neither the differences between proposers and responders, within the respective treatment, nor the difference between treatment, are statistically significant however. The reason for 2) is that we find, as others have before, that more risk averse proposers offer a larger share to their matched responders, most likely in order to minimize the risk of rejection (regressing proposer's offer to the responder on a measure of the willingness to take risk, without any additional controls, yields a coefficient of $\beta=-0.183$ with $p=0.036$ ). This, in combination with the gender difference in risk aversion (a finding documented in among others Croson and
} 
Figure 1: Lower Offers in the Entitlement Treatment

A (Entitlement Treatment)

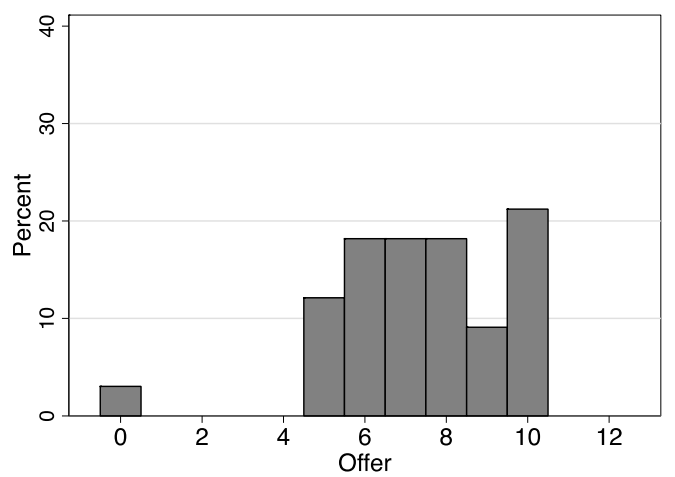

B (Random Treatment)

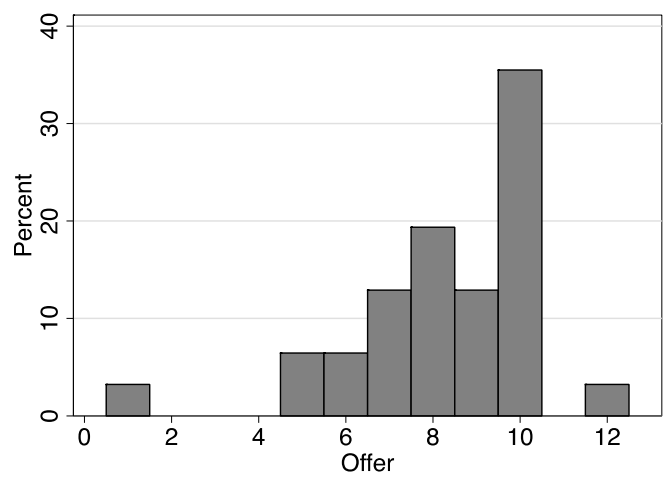

We next turn to our main point of interest, namely if women and men react differently to having earned the right to be the proposer, as opposed to simply having it randomly allocated. Figure 2 breaks down the data by treatment and by the gender of the proposer.

When acting as proposers, women offer, on average, $\$ 8.44$ in the Random Treatment and \$6.57 in the Entitlement Treatment. This difference of \$1.87 is twice as big as for the average sample, and it is statistically significant ( $\mathrm{p}=0.012$ with WMW test, and $\mathrm{p}=0.018$ with Wald test). Male proposers, on the other hand, behave quite similarly between the two treatments - they offer $\$ 8.13$ to the responder in the Random Treatment and $\$ 7.95$ in the Entitlement Treatment (this difference of $\$ 0.18$ is not statistically different from zero, $\mathrm{p}=0.521$ with WMW test and $\mathrm{p}=0.827$ with Wald test). The difference in difference of $\$ 1.69$ is marginally statistically significant ( $\mathrm{p}=0.089$ with t-test), offering

Gneezy, 2009; Gärtner et al., 2017; and something that we also replicate, with women scoring 6.12 and men 6.85 on a qualitative $1-10$ willingness to take risk scale, $\mathrm{p}=0.033$ with WMW test and $\mathrm{p}=0.073$ with $\mathrm{t}$ test), makes also controlling for risk aversion the most prudent option. It should be noted that the results reported here hold also when controlling only for one of these variables or for none of them (reported in the Online Appendix). 
further support for female and male proposers' reaction to the Entitlement treatment indeed being different.

Figure 2: Women React to Entitlements, but Men Do Not

\section{A (Entitlement Treatment, Women)}

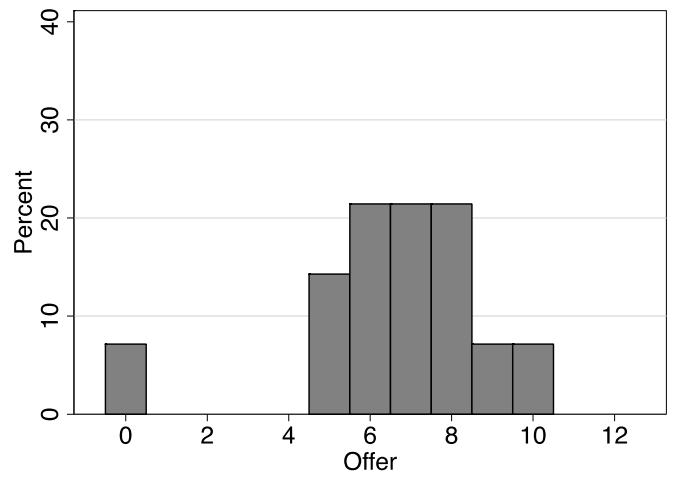

C (Entitlement Treatment, Men)

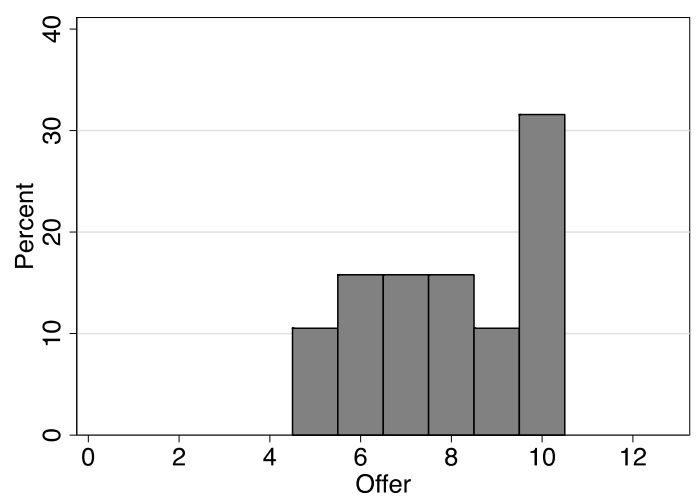

B (Random Treatment, Women)

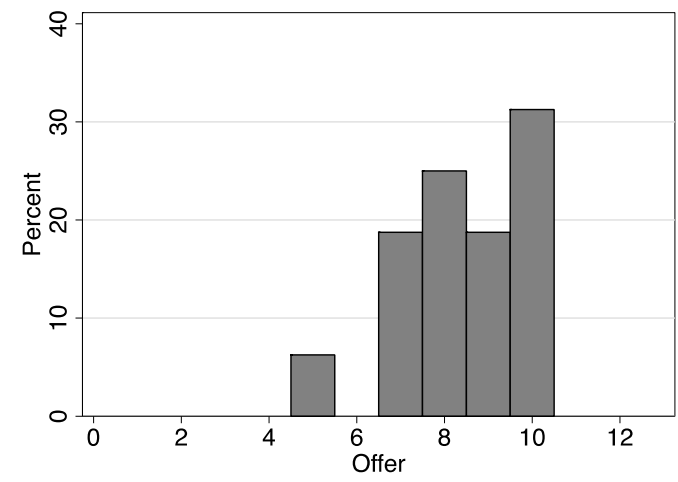

D (Random Treatment, Men)

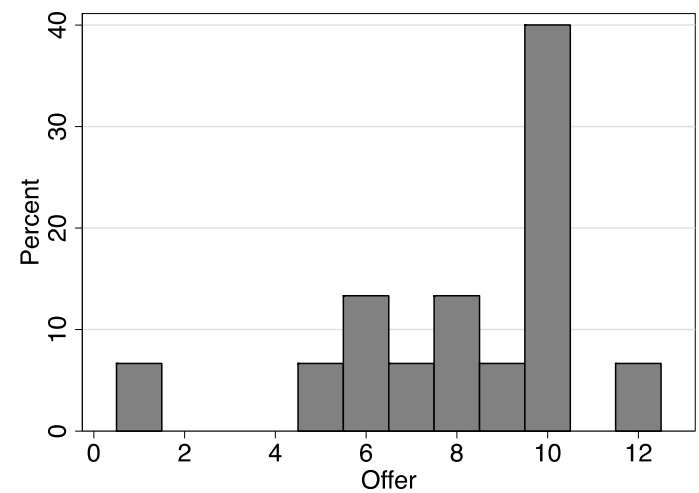

This also implies that, in the Random treatment, we replicate the finding from Solnick (2001) of there being no gender difference in proposers' behavior in the Ultimatum Game (female responders offer $\$ 0.30$ more than males, but this difference is statistically insignificant, $\mathrm{p}=0.887$ with WMW test and $\mathrm{p}=0.566$ with Wald test). In the Entitlement treatment we do, however, find a significant gender difference: here female proposers offer $\$ 1.38$ less than men ( $\mathrm{p}=0.099$ with WMW test and $\mathrm{p}=0.011$ with Wald test). 


\subsection{Minimum Acceptable Offers - Responder's Behavior and Proposer's Beliefs}

Our findings are consistent with those of Hoffman et al. (1994), also in that we do not observe a significant change in rejection rates between the treatments $(p=0.447$ with $t$-test for proportions). The minimum acceptable offers stated by the responders were on average $\$ 4.77$ in the Random treatment and $\$ 5.03$ in the Entitlement treatment $(\mathrm{p}=0.722$ with WMW test and $\mathrm{p}=0.720$ with Wald test). This is true for both male and female responders: Male responders stated a mean minimum acceptable offer of \$4.59 in the Random treatment and $\$ 5.64$ in the Entitlement treatment, p=0.342 with WMW test and p=0.365 with Wald test). The mean minimum acceptable offer of female responders was \$5.00 in the Random and $\$ 4.73$ in the Entitlement treatment $(\mathrm{p}=0.653$ with WMW test and $\mathrm{p}=0.793$ with Wald test).

When analyzing the data from the belief elicitation, we note that although responders' behavior does not change between the treatments, proposers believe that it does. The change in proposers' beliefs is in line with their change in behavior between treatments. In the Random treatment, proposers believe that the minimum acceptable offer of their paired responder was $\$ 5.29$, and this decreases to $\$ 4.79$ in the Entitlement treatment (however, this difference is not statistically significant, $\mathrm{p}=0.310$ with WMW test and $\mathrm{p}=0.328$ with Wald test). Just as for the treatment difference in proposers' behavior, we see that while there are indications that women's beliefs are affected by the treatment, this is not the case for men. Female proposers believe the minimum acceptable offer of the paired responder to be $\$ 5.19$ in the Random treatment and \$4.29 in the Entitlement treatment, 
$\mathrm{p}=0.334$ with WMW test and $\mathrm{p}=0.098$ with Wald test. The corresponding figures for male proposers are $\$ 5.40$ and $\$ 5.16, p=0.445$ with $W M W$ test and $p=0.976$ with Wald test.

\subsection{Math Scores and Confidence}

Female participants gave an average of 7.92 correct answers in part one of the experiment, whereas male participants gave 7.08 ( $\mathrm{p}=0.120$ with WMW test and $\mathrm{p}=0.083$ with t-test). There was no significant difference in performance between treatments (average score was 7.42 in the Random treatment and 7.61 in the Entitlement treatment, $\mathrm{p}=0.799$ with WMW test and $\mathrm{p}=0.703$ with $\mathrm{t}$-test).

In order to investigate confidence, we use the belief measures from the third part of the experiment. We consider two types of confidence (cf. Moore and Healy, 2008), with the first being overestimation, i.e. to what extent does a person believe that she performed better than she actually did in the math task. To measure this we take the difference between the score that the participant believed she achieved (as stated in the incentivized belief elicitation stage) and her actual score. The other type of confidence that we consider is over-placement, i.e. how a participant believes that her own score compares to others'. We measure this as the difference between the score that the participant believed she achieved and her belief about the average score of others participating in the same session.

We are interested in how confidence relate to proposers' behavior. Starting with our first concept of confidence, overestimation, we note that the point estimates indicate that female proposers slightly underestimate and male proposers slightly overestimate their own score in the Random treatment (women underestimate their score by 0.56 on average and men overestimate their score by 0.13 on average, $\mathrm{p}=0.243$ with WMW test and $\mathrm{p}=0.402$ 
with Wald test ${ }^{4}$ ). Being assigned the proposer role in the Entitlement treatment boosts especially female proposers' confidence in this regard and they now over-estimate their own score by 0.93 , which is a significant difference from the Random treatment ( $\mathrm{p}=0.022$ with WMW test and $\mathrm{p}=0.007$ with Wald test). Male proposers' overestimation of 1.00 is also higher in the Entitlement treatment, albeit at most marginally statistically significantly so $(\mathrm{p}=0.239$ with WMW test and $\mathrm{p}=0.087$ with Wald test).

Considering instead our second confidence concept, over-placement, we find that in the Random treatment, female proposers on average believe that they scored exactly similar to other participants (average over-placement value of 0.00 ) whereas male proposers predict that they gave 1.33 more correct answers than the others in the same session (the gender difference is significant, $\mathrm{p}=0.036$ with WMW test and $\mathrm{p}=0.001$ with Wald test). In the Entitlement treatment, proposers' average over-placement rise especially for women. Female proposers now believe to have done 2.5 more tasks correctly that the others in the room (a highly significant change, $\mathrm{p}=0.003$ with WMW test and $\mathrm{p}=0.002$ with Wald test, when comparing with the Random treatment). Male proposers' over-placement increases to 2.47 ( $\mathrm{p}=0.108$ with WMW test and $\mathrm{p}=0.069$ with Wald test). In the Entitlement treatment there is hence no longer a statistically significant difference between the degree to which men and women over-place themselves ( $\mathrm{p}=0.795$ with WMW test and $\mathrm{p}=0.147$ with Wald test).

\subsection{Fairness Considerations and Feelings of Deservingness}

\footnotetext{
${ }^{4}$ The Wald tests in this and the next section control for score in part 1 in order to not confuse our measures of confidence and fairness with differences in ability, controlling for risk aversion would however not be accurate and hence we refrain from that here. (However, the Online Appendix makes clear that our results are not sensitive to which exact controls are included.)
} 
In the post-experimental questionnaire, we asked all participants unincentivized questions about what the fair distribution of $\$ 20$ in the pair would be, asking the subjects to take the perspective of a disinterested third party. We find that female proposers believe that a fair allocation to the proposer is $\$ 10.38$ in the Random treatment and $\$ 12.07$ in the Entitlement treatment ( $\mathrm{p}=0.003$ with WMW test and $\mathrm{p}=0.002$ with Wald test). For male proposers the corresponding figures are $\$ 11.47$ and $\$ 12.21$ ( $\mathrm{p}=0.066$ with WMW test and $\mathrm{p}=0.484$ with Wald test). Responders' stated fairness views are similar (see the Online Appendix).

We also asked participants to report feelings of deservingness. Specifically we used a 1 to 10 Likert scale asking proposers if they believe that they deserved to be the proposer (1 was defined as not deserving this role at all and 10 as definitely deserving it). We document that both female and male proposers consider themselves more deserving in the Entitlement treatment than the in Random treatment (7.44 for females and 7.13 for males in the Random treatment, and 8.79 for females and 9.26 for males in the Entitlement treatment). The difference between the treatments is significant for both female and male proposers $(\mathrm{p}=0.067$ and $\mathrm{p}=0.002$ with WMW test, and $\mathrm{p}=0.063$ and $\mathrm{p}=0.001$ with Wald test, for women and men respectively). Responders were asked how deserving they regarded their matched proposer to be. The results are similar to what is observed for the proposers, see the Online Appendix.

\subsection{Strategic Thinking}


As discussed above, we find that female, but not male, proposers change their beliefs about the responders' minimum acceptable offers between our two treatments. Here we continue to investigate the relation between proposers' offers and their beliefs about the responders' behavior.

A payoff maximizing proposer holding the (on average correct) belief that their matched responder will not accept offers that are "too low" should make an offer based on their beliefs about what constitutes a minimum acceptable offer. To investigate if proposers are strategic in this sense we test for the correlation between offers and beliefs about the matched responder's minimum acceptable offer. In our Random treatment, female proposers' offers and beliefs are not correlated (Spearman's rho $=-0.008, \mathrm{p}=0.976$ ). This, however, changes in the Entitlement treatment where female proposers make offers which significantly correlate with their beliefs (Spearman's rho $=0.800 . \mathrm{p}=0.001$ ). Male proposers, on the other hand, base their offers on their expectations both in the Random (Spearman's rho $=0.486, \mathrm{p}=0.066$ ) and, to some extent, in the Entitlement treatment (Spearman's rho $=0.280, p=0.246)$. The different patterns are outlined in Figure 3.

This suggests that gender differences in negotiation behavior may be impacted by entitlements. While male proposers appear to behave strategically in the UG regardless of whether they earned the proposer role or not, women seem to do so only in the presence of entitlements.

Figure 3: Correlation Between Proposers' Offers and their Beliefs About Minimum Acceptable Offers
A (Entitlement Treatment, Women)
B (Random Treatment, Women) 


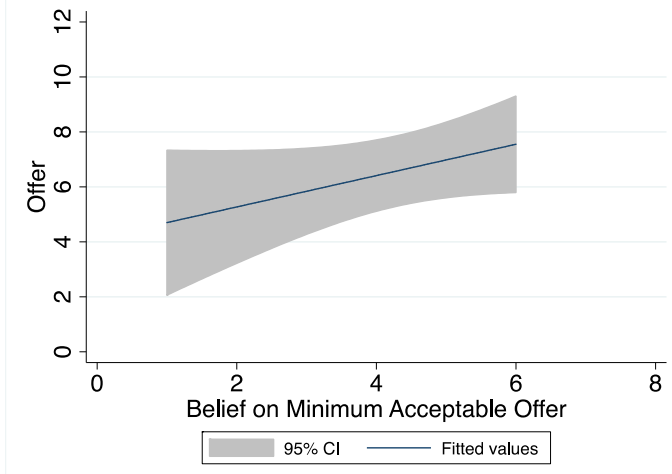

C (Entitlement Treatment, Men)

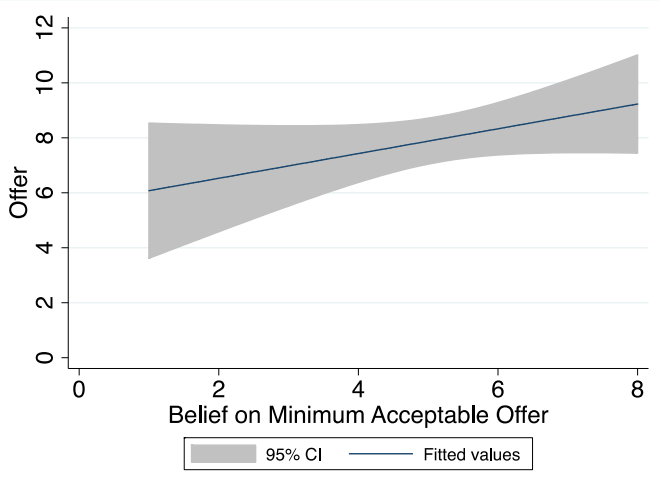

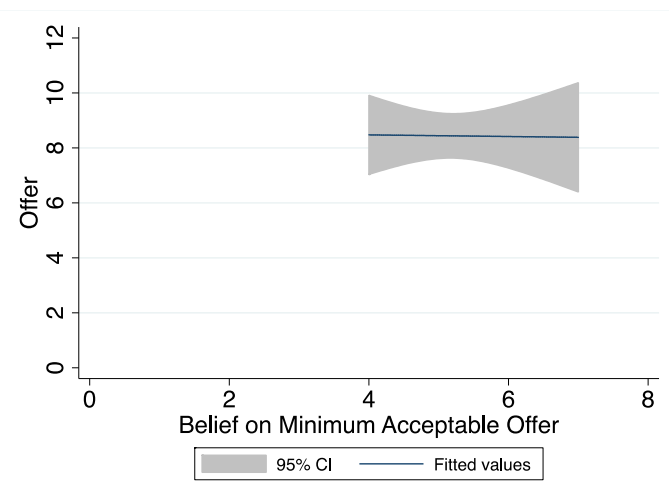

D (Random Treatment, Men)

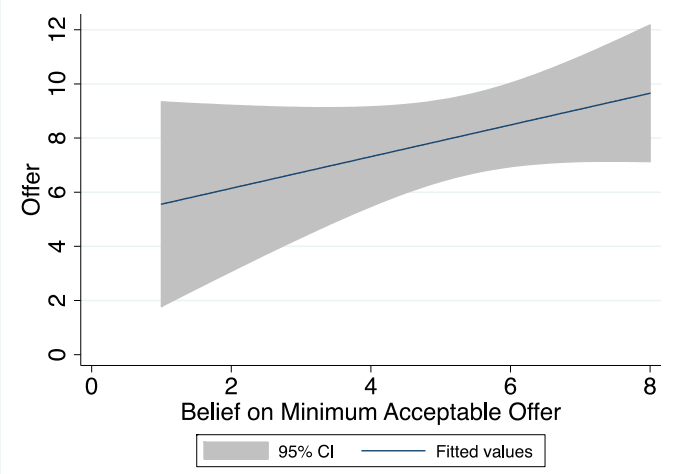

\section{Concluding Remarks}

In a one-shot UG, we find that female proposers, but not male, react to entitlements by making tougher strategic demands and offering a lower share of the endowment to their matched responder. Further only female proposers believe that responders have a lower threshold for accepting an offer in the Entitlement treatment. Women also become significantly more confident regarding their performance, and change their strategic behavior.

Our findings are in line with others documenting that women are more responsive to context and social cues. Moreover, they have implications for labor market behavior in that they indicate that strengthening both women's and men's feelings of entitlement (something that could potentially be accomplished for example through more transparent 
recruitment processes) can have a greater effect on women's bargaining, hence helping to close the gender negotiation gap. 


\section{References:}

Apicella, Coren L., Elif E. Demiral, and Johanna Mollerstrom. "Gender Differences in Self- and Other-competition.” (2017). Working paper.

Babcock, Linda, Sara Laschever, Michele Gelfand, and Deborah Small. “Nice Girls Don’t Ask.” Harvard Business Review, 81, no. 10 (2003).

Babcock, Linda and Sara Laschever. Women Don't Ask: Negotiation and the Gender Divide. Princeton: Princeton University Press, 2003.

Banerjee, Priyodorshi, and Sujoy Chakravarty. "Psychological ownership, group affiliation and other-regarding behaviour: Some evidence from dictator games." Global Economics and Management Review 19, no. 1 (2014): 3-15.

Barron, Lisa A. “Ask and You Shall Receive? Gender Differences in Negotiators’ Beliefs about Requests for a Higher Salary.” Human Relations 56, no. 6 (2003): 635-662.

Cherry, Todd L. "Mental accounting and other-regarding behavior: Evidence from the lab." Journal of Economic Psychology 22, no. 5 (2001): 605-615.

Cherry, Todd L., Peter Frykblom, and Jason F. Shogren. "Hardnose the dictator." The American Economic Review 92, no. 4 (2002): 1218-1221. 
Croson, Rachel, and Uri Gneezy. “Gender Differences in Preferences.” Journal of Economic Literature 47, no. 2 (2009): 448-474.

Deaux, Kay, and Elizabeth Farris. “Attributing Causes for One’s Own Performance: The Effects of Sex, Norms, and Outcome.” Journal of Research in Personality 11, no. 1 (1977): $59-72$.

Dittrich, Marcus, Andreas Knabe, And Kristina Leipold. "Gender Differences In Experimental Wage Negotiations.” Economic Inquiry 52, no 2 (2014): 862-873.

Eckel, Catherine C., and Philip J. Grossman. "Chivalry and Solidarity in Ultimatum Games.” Economic Inquiry 39, no. 2 (2001): 171-188.

Ellingsen, Tore, Magnus Johannesson, Johanna Mollerstrom, and Sara Munkhammar. “Gender Differences in Social Framing Effects.” Economics Letters 118, no. 3 (2013): $470-472$.

Exley, Christine L., Muriel Niederle, and Lise Vesterlund. Knowing When to Ask: The Cost of Leaning In. (2017). National Bureau of Economic Research Working Paper, No. w22961.

Fischbacher, Urs. “Z-Tree: Zurich Toolbox for Ready-Made Economic Experiments.” Experimental Economics 10, no. 2 (2007): 171-178. 
Gärtner, Manja, Johanna Mollerstrom, and David Seim. "Individual risk preferences and the demand for redistribution." Journal of Public Economics 153 (2017): 49-55.

Gelfand, Michele, and Heidi Stayn. "Gender differences in the propensity to initiate negotiations." In Social Psychology and Economics. Edited by David De Cremer, Marcel Zeelenberg, J. Keith Murnighan, New York: Psychology Press, 239-263, 2012.

Hoffman, Elizabeth, Kevin McCabe, Keith Shachat, and Vernon Smith. "Preferences, Property Rights, and Anonymity in Bargaining Games.” Games and Economic Behavior 7, no. 3 (1994): 346-380.

Hoffman, Elizabeth and Matthew Spitzer. "Entitlements, rights, and fairness: An experimental examination of subjects' concepts of distributive justice.” Journal of Legal Studies, 14, no. 2 (1985): 259-297.

Kaman, Vicki S., and Charmine E.J. Hartel. 1994. “Gender Differences in Anticipated Pay Negotiation Strategies and Outcomes.” Journal of Business and Psychology 9, no. 2 (1994): 183-197.

Korenok, Oleg, Edward Millner, and Laura Razzolini. "Feelings of ownership in dictator games." Journal of Economic Psychology 61 (2017): 145-151. 
Leibbrandt, Andreas, and John A. List. "Do Women Avoid Salary Negotiations? Evidence from a Large-Scale Natural Field Experiment.” Management Science 61, no. 9 (2014): 2016-2024.

Major, Brenda, Dean B. McFarlin, and Diana Gagnon. “Overworked and Underpaid: On the Nature of Gender Differences in Personal Entitlement.” Journal of Personality and Social Psychology 47, no. 6 (1984): 1399-1412.

Moore, Don A., and Paul J. Healy. "The Trouble with Overconfidence.” Psychological Review 115, no. 2 (2008): 502-517.

Niederle, Muriel, and Lise Vesterlund. "Do Women Shy Away From Competition? Do Men Compete Too Much?” The Quarterly Journal of Economics 122, no. 3 (2007): 10671101.

Oxoby, Robert J., and John Spraggon. "Mine and yours: Property rights in dictator games." Journal of Economic Behavior \& Organization 65, no. 3 (2008): 703-713.

Rigdon, Mary. “An Experimental Investigation of Gender Differences in Wage Negotiations.” (2012). Working Paper. Available at SSRN 2165253, 1-33. http://www.academia.edu/download/30236446/Rigdon_GenderDifferencesWages.pdf. 
Small, Deborah A., Michele Gelfand, Linda Babcock, and Hilary Gettman. "Who Goes to the Bargaining Table? The Influence of Gender and Framing on the Initiation of Negotiation.” Journal of Personality and Social Psychology 93, no. 4 (2007): 600-613.

Solnick, Sara. “Gender Differences in the Ultimatum Game.” Economic Inquiry 39, no. 2 (2001): 189-200.

Stevens, Cynthia K., Anna G. Bavetta, and Marilyn E. Gist. “Gender Differences in the Acquisition of Salary Negotiation Skills: The Role of Goals, Self-Efficacy, and Perceived Control.” The Journal of Applied Psychology 78, no. 5 (1993): 723-735. 


\section{Appendix A: Robustness Checks and Additional Analysis}

Table A1 : Robustness Checks for Proposer Behavior (Offers)

\begin{tabular}{|c|c|c|c|c|c|c|c|c|c|}
\hline & & & & & $p$-values & $r$ gender $\mathrm{c}$ & fference & & \\
\hline & & Women & Men & Total & t-test & $\begin{array}{l}\text { Wald } \\
\text { test, } \\
\text { Risk } \\
\text { Control }\end{array}$ & $\begin{array}{l}\text { Wald } \\
\text { test, } \\
\text { Score }\end{array}$ & $\begin{array}{l}\text { Wald } \\
\text { test, } \\
\text { Risk } \\
\text { and } \\
\text { Score } \\
\end{array}$ & $\begin{array}{l}\text { WMW } \\
\text { test }\end{array}$ \\
\hline & Random & 8.44 & 8.13 & 8.29 & $p=0.703$ & $p=0.711$ & $p=0.560$ & $p=0.566$ & $p=0.887$ \\
\hline & Entitlement & 6.57 & 7.95 & 7.36 & $p=0.068$ & $p=0.018$ & $p=0.093$ & $p=0.011$ & $p=0.099$ \\
\hline & Total & 7.57 & 8.03 & 7.81 & $p=0.403$ & $p=0.293$ & $p=0.696$ & $p=0.530$ & $p=0.348$ \\
\hline & t-test & $p=0.014$ & $p=0.815$ & $p=0.091$ & & & & & \\
\hline $\begin{array}{c}\text { for } \\
\text { treatment }\end{array}$ & $\begin{array}{l}\text { Wald test, Risk } \\
\text { Control }\end{array}$ & $p=0.018$ & $p=0.884$ & $p=0.129$ & & & & & \\
\hline & $\begin{array}{l}\text { Wald test, } \\
\text { Score }\end{array}$ & $p=0.016$ & $p=0.859$ & $p=0.110$ & & & & & \\
\hline & $\begin{array}{l}\text { Wald test, Risk } \\
\text { and Score }\end{array}$ & $p=0.018$ & $p=0.827$ & $p=0.155$ & & & & & \\
\hline & WMW test & $p=0.012$ & $p=0.521$ & $p=0.050$ & & & & & \\
\hline
\end{tabular}

Notes: All p-values reported in Section 3.1 of the paper are robust to controlling only for risk or task score, and neither risk nor task score.

Table A2: The Difference in Difference Regressions for the Offers

\begin{tabular}{|c|c|c|c|c|c|c|}
\hline & $(1)$ & $(2)$ & (3) & (4) & (5) & $(6)$ \\
\hline Entitlement & $\begin{array}{l}-0.927^{*} \\
(0.539)\end{array}$ & $\begin{array}{c}-0.977 * \\
(0.563)\end{array}$ & $\begin{array}{l}-0.186 \\
(0.828)\end{array}$ & $\begin{array}{c}0.021 \\
(0.815)\end{array}$ & $\begin{array}{c}-0.137 \\
(0.834)\end{array}$ & $\begin{array}{c}0.068 \\
(0.809)\end{array}$ \\
\hline Female & & $\begin{array}{c}0.553 \\
(0.558)\end{array}$ & $\begin{array}{c}0.304 \\
(0.802)\end{array}$ & $\begin{array}{c}0.314 \\
(0.821)\end{array}$ & $\begin{array}{c}0.484 \\
(0.827)\end{array}$ & $\begin{array}{c}0.492 \\
(0.828)\end{array}$ \\
\hline \multicolumn{2}{|c|}{ Entitlement*Female } & & $\begin{array}{l}-1.680 \\
(1.103)\end{array}$ & $\begin{array}{l}-1.924^{*} \\
(1.104)\end{array}$ & $\begin{array}{l}-1.604 \\
(1.070)\end{array}$ & $\begin{array}{l}-1.848 * \\
(1.068)\end{array}$ \\
\hline Risk Taking & & & & $\begin{array}{c}-0.205^{* *} \\
(0.081)\end{array}$ & & $\begin{array}{c}-0.204 * * \\
(0.084)\end{array}$ \\
\hline Math Score & & & & & $\begin{array}{c}-0.143 \\
(0.125)\end{array}$ & $\begin{array}{c}-0.141 \\
(0.123)\end{array}$ \\
\hline Constant & $\begin{array}{c}8.290 * * * \\
(0.388)\end{array}$ & $\begin{array}{c}8.576^{* * *} \\
(0.575)\end{array}$ & $\begin{array}{c}8.133 * * * \\
(0.715)\end{array}$ & $\begin{array}{c}9.404^{* * *} \\
(0.739)\end{array}$ & $\begin{array}{c}9.112^{* * *} \\
(1.003)\end{array}$ & $\begin{array}{c}10.365^{* * *} \\
(1.090)\end{array}$ \\
\hline $\mathrm{N}$ & 64 & 64 & 64 & 64 & 64 & 64 \\
\hline R-square & 0.046 & 0.062 & 0.098 & 0.149 & 0.126 & 0.176 \\
\hline
\end{tabular}

Notes: This table reports the difference-indifference regressions as mentioned in Section 3.1 of the paper.

Robust se in parentheses. Dependent variable is the offer made by the proposers. Risk is a 1-10 self-

assessed index of willingness to take risk with $1=$ "Not at all willing to take risks" and 10= "Very willing to take risk". Score is the number of correct answers given in the first part of the experiment. ${ }^{* * *} p<0.01$, ** $p<0.05,{ }^{*} p<0.1$. 
Table A3: Minimum Acceptable Offers

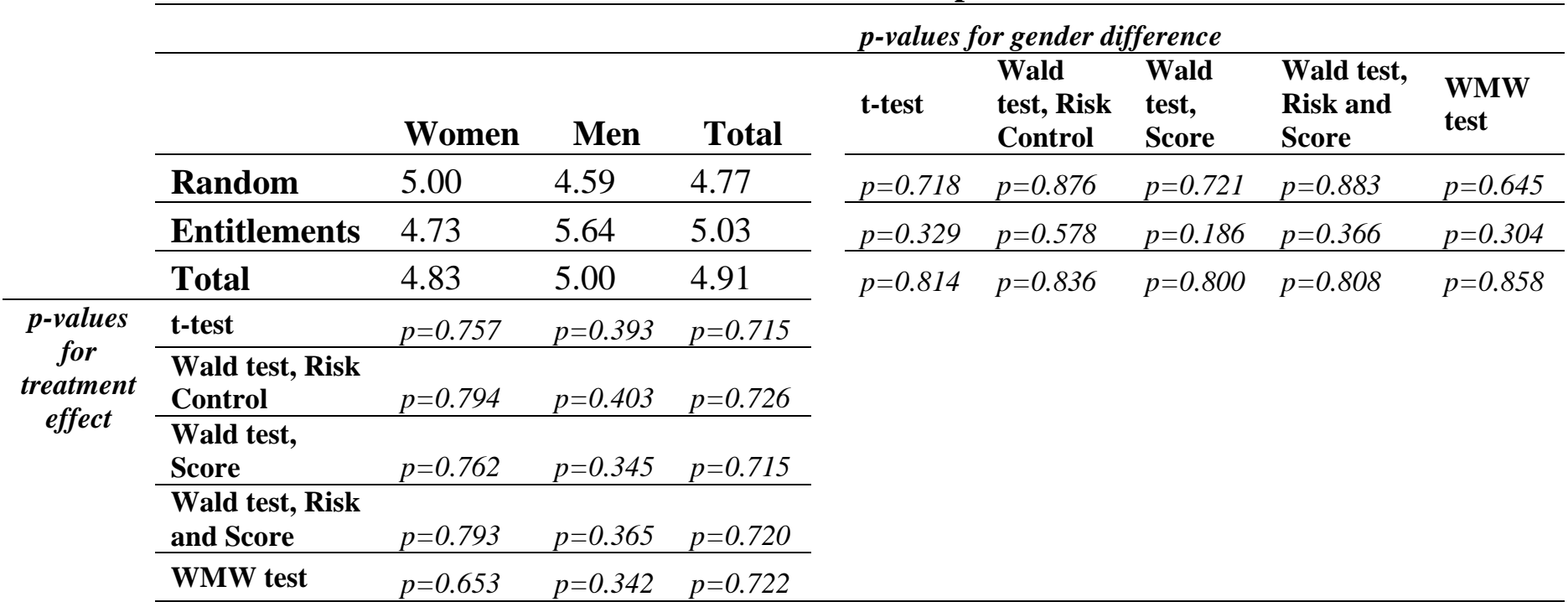

Notes: All p-values reported in Section 3.2 of the paper are robust to controlling only for risk or task score, and neither risk nor task score.

Table A4: Robustness Checks for Proposers' Belief about Minimum Acceptable Offers

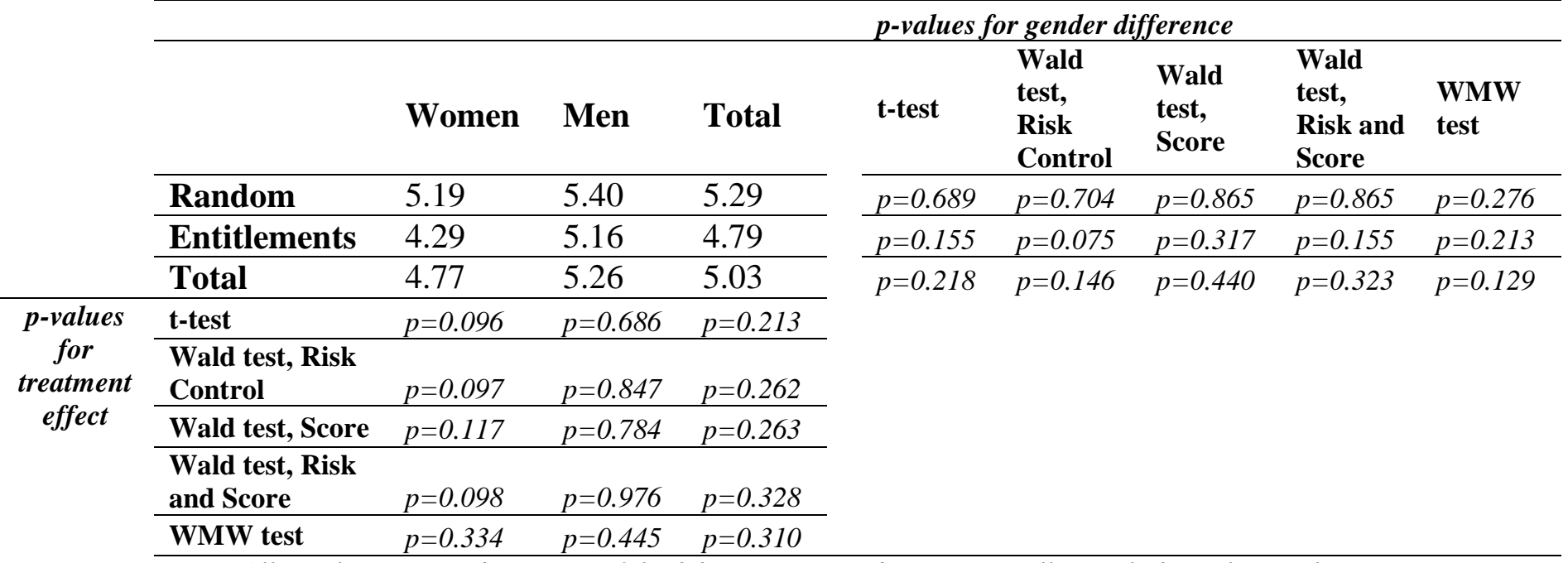

Notes: All p-values reported in Section 3.2 of the paper are robust to controlling only for risk or task score, and neither risk nor task score. 
Table A5: Summary of the Analysis on Math Scores in Part 1

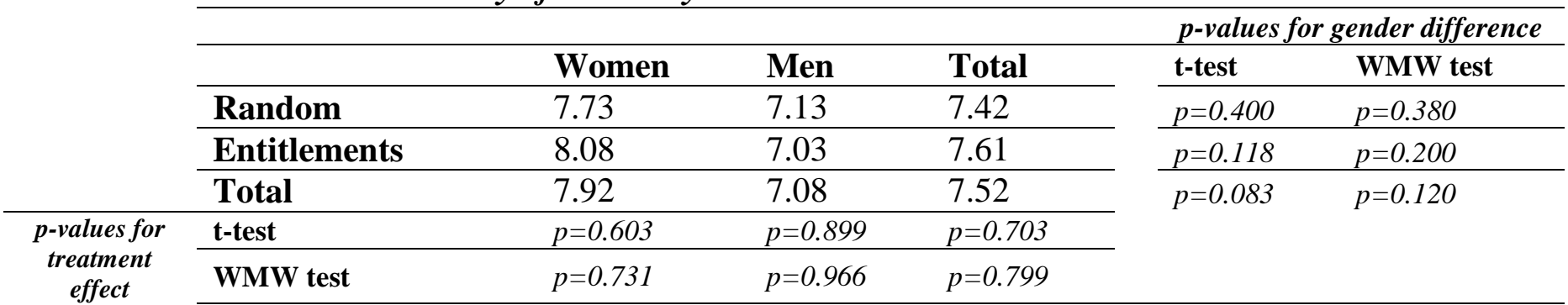

Notes: This table summarizes the math score of participants in Task 1 as mentioned in footnote 3 under Section 3.1 and in the main text of Section 3.3 of the paper.

Table A6: Robustness Checks for Proposers' Overestimation of Their Score

\begin{tabular}{|c|c|c|c|c|c|c|c|c|c|}
\hline & & \multirow[b]{2}{*}{ Women } & \multirow[b]{2}{*}{ Men } & \multicolumn{6}{|c|}{ p-values for gender difference } \\
\hline & & & & Total & t-test & $\begin{array}{l}\text { Wald } \\
\text { test, } \\
\text { Risk } \\
\text { Control } \\
\end{array}$ & $\begin{array}{l}\text { Wald } \\
\text { test, } \\
\text { Score }\end{array}$ & $\begin{array}{l}\text { Wald test, } \\
\text { Risk and } \\
\text { Score }\end{array}$ & $\begin{array}{l}\text { WMW } \\
\text { test }\end{array}$ \\
\hline & Random & -0.56 & 0.13 & -0.23 & $p=0.228$ & $p=0.233$ & $p=0.402$ & $p=0.404$ & $p=0.243$ \\
\hline & Entitlements & 0.93 & 1.00 & 0.97 & $p=0.907$ & $p=0.994$ & $p=0.805$ & $p=0.771$ & $p=0.941$ \\
\hline & Total & 0.13 & 0.62 & 0.39 & $p=0.268$ & $p=0.312$ & $p=0.526$ & $p=0.592$ & $p=0.427$ \\
\hline \multirow{5}{*}{$\begin{array}{l}\text { p-values } \\
\text { for } \\
\text { treatment } \\
\text { effect }\end{array}$} & t-test & $p=0.007$ & $p=0.181$ & $p=0.005$ & & & & & \\
\hline & $\begin{array}{l}\text { Wald test, Risk } \\
\text { Control }\end{array}$ & $p=0.007$ & $p=0.228$ & $p=0.006$ & & & & & \\
\hline & $\begin{array}{l}\text { Wald test, } \\
\text { Score }\end{array}$ & $p=0.007$ & $p=0.087$ & $p=0.002$ & & & & & \\
\hline & $\begin{array}{l}\text { Wald test, Risk } \\
\text { and Score }\end{array}$ & $p=0.008$ & $p=0.145$ & $p=0.003$ & & & & & \\
\hline & WMW test & $p=0.022$ & $p=0.239$ & $p=0.014$ & & & & & \\
\hline
\end{tabular}

Notes: All p-values reported in Section 3.3 of the paper are robust to controlling only for risk or task score, and neither risk nor task score. 
Table A7: Robustness Checks for Proposers' Over-placement

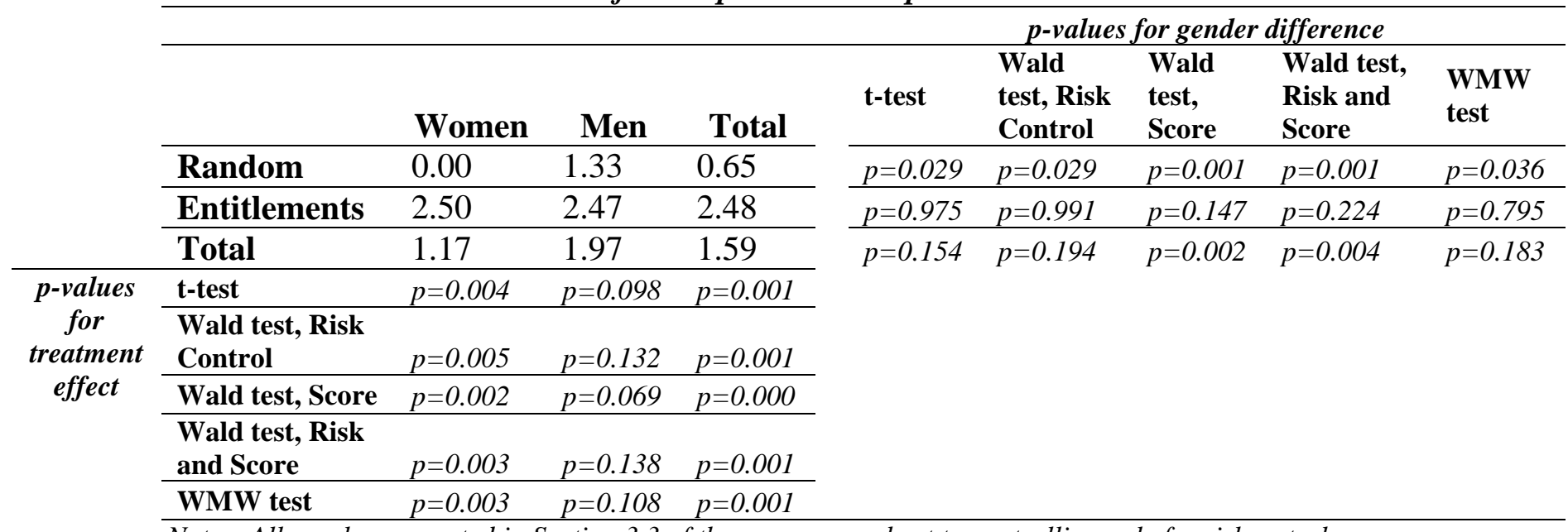

Notes: All p-values reported in Section 3.3 of the paper are robust to controlling only for risk or task score,

and neither risk nor task score.

Table A8: Robustness Checks for Proposers' Fairness Considerations

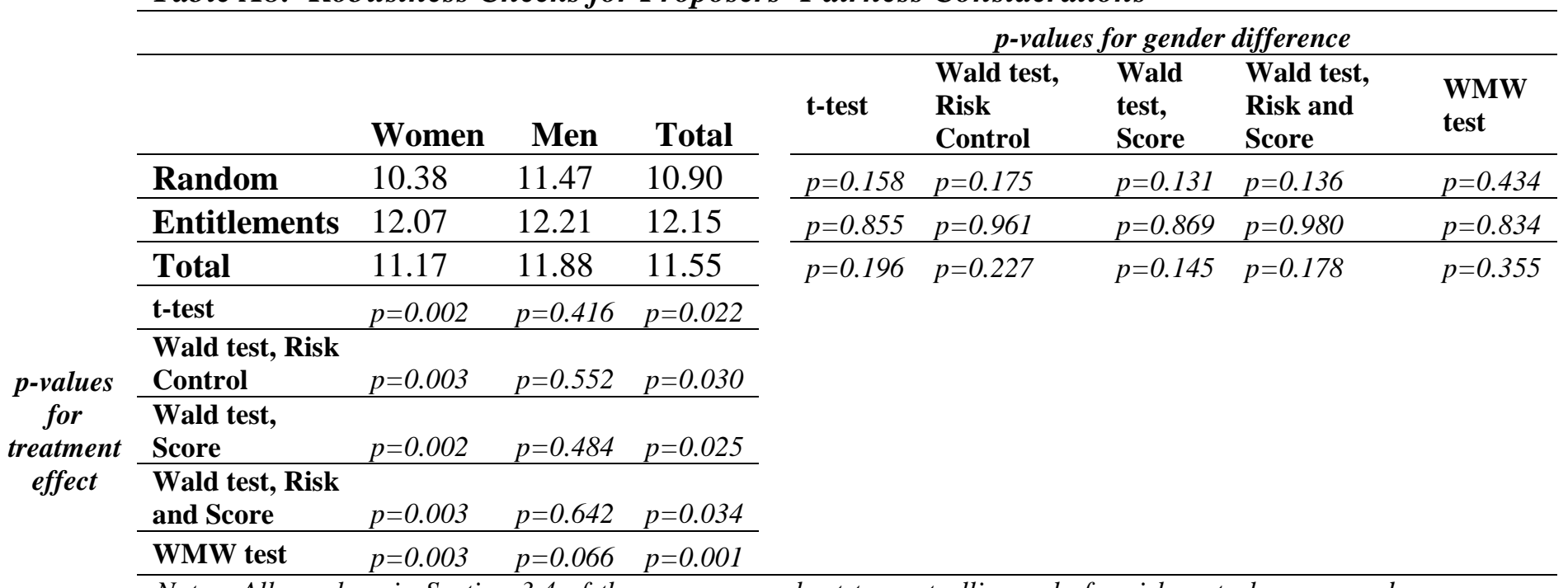

Notes: All p-values in Section 3.4 of the paper are robust to controlling only for risk or task score, and neither risk nor task score. 
Table A9: Details about Responders' Stated Fair Distribution

\begin{tabular}{|c|c|c|c|c|c|c|c|c|c|}
\hline & & \multirow[b]{2}{*}{ Women } & \multirow[b]{2}{*}{ Men } & \multirow[b]{2}{*}{ Total } & \multicolumn{5}{|c|}{ p-values for gender difference } \\
\hline & & & & & \multicolumn{2}{|r|}{$\begin{array}{l}\text { Wald } \\
\text { test, Risk } \\
\text { Control }\end{array}$} & \multirow{2}{*}{$\begin{array}{l}\begin{array}{l}\text { Wald } \\
\text { test, } \\
\text { Score }\end{array} \\
p=0.996\end{array}$} & \multirow[t]{2}{*}{$\begin{array}{l}\begin{array}{l}\text { Wald } \\
\text { test, Risk } \\
\text { and } \\
\text { Score }\end{array} \\
p=0.842\end{array}$} & $\begin{array}{l}\text { WMW } \\
\text { test }\end{array}$ \\
\hline & Random & 10.43 & 10.41 & 10.42 & $p=0.965$ & $p=0.839$ & & & $p=0.852$ \\
\hline & Entitlements & 11.54 & 12.73 & 11.94 & $p=0.131$ & $p=0.229$ & $p=0.159$ & $p=0.321$ & $p=0.100$ \\
\hline & Total & 11.11 & 11.32 & 11.20 & $p=0.652$ & $p=0.887$ & $p=0.667$ & $p=0.929$ & $p=0.516$ \\
\hline \multirow{13}{*}{$\begin{array}{l}\text { p-values } \\
\text { for } \\
\text { treatment } \\
\text { effect }\end{array}$} & t-test & $p=0.069$ & $p=0.001$ & $p=0.001$ & & & & & \\
\hline & $\begin{array}{l}\text { Wald test, Risk } \\
\text { Control } \\
\end{array}$ & $p=0.078$ & $p=0.002$ & $p=0.001$ & & & & & \\
\hline & $\begin{array}{l}\text { Wald test, } \\
\text { Score }\end{array}$ & $p=0.049$ & $p=0.003$ & $p=0.000$ & & & & & \\
\hline & $\begin{array}{l}\text { Wald test, Risk } \\
\text { and Score }\end{array}$ & $p=0.084$ & $p=0.004$ & $p=0.001$ & & & & & \\
\hline & WMW test & $p=0.062$ & $p=0.000$ & $p=0.000$ & & & & & \\
\hline & $\begin{array}{l}\text { Notes: As stated in } \\
\text { similar to proposer } \\
\text { and neither risk no }\end{array}$ & $\begin{array}{l}\text { n Section } 3 . \\
\text { rs' fairness } \\
\text { or task score }\end{array}$ & $\begin{array}{l}\text { of the pap } \\
\text { iews. All p- }\end{array}$ & $\begin{array}{l}r \text {, responde } \\
\text { alues here }\end{array}$ & $\begin{array}{l}\text { perceived } \\
\text { robust to }\end{array}$ & $\begin{array}{l}\text { fair allocatio } \\
\text { ontrolling on }\end{array}$ & $\begin{array}{l}n \text { to propos } \\
\text { ly for risk o }\end{array}$ & $\begin{array}{l}\text { ers are very } \\
\text { r task score, }\end{array}$ & \\
\hline & Table A10: $R$ & obustness & Checks fo & $r$ Propose & Feeling & of Deservi & ngness & & \\
\hline & & & & & & $p$-values $f$ & For gender & lifference & \\
\hline & & Women & Men & Total & t-test & $\begin{array}{l}\text { Wald } \\
\text { test, Risk } \\
\text { Control }\end{array}$ & $\begin{array}{l}\text { Wald } \\
\text { test, } \\
\text { Score }\end{array}$ & $\begin{array}{l}\text { Wald test, } \\
\text { Risk and } \\
\text { Score }\end{array}$ & WMW \\
\hline & Random & 7.44 & 7.13 & 7.29 & $p=0.683$ & $p=0.690$ & $p=0.557$ & $p=0.538$ & $p=0.699$ \\
\hline & Entitlements & 8.79 & 9.26 & 9.06 & $p=0.345$ & $p=0.386$ & $p=0.454$ & $p=0.496$ & $p=0.397$ \\
\hline & Total & 8.07 & 8.32 & 8.20 & $p=0.601$ & $p=0.706$ & $p=0.692$ & $p=0.791$ & $p=0.602$ \\
\hline & t-test & $p=0.064$ & $p=0.001$ & $p=0.001$ & & & & & \\
\hline \multirow{4}{*}{$\begin{array}{c}p \text {-values } \\
\text { for } \\
\text { treatment } \\
\text { effect }\end{array}$} & $\begin{array}{l}\text { Wald test, Risk } \\
\text { Control }\end{array}$ & $p=0.057$ & $p=0.001$ & $p=0.000$ & & & & & \\
\hline & $\begin{array}{l}\text { Wald test, } \\
\text { Score }\end{array}$ & $p=0.063$ & $p=0.001$ & $p=0.000$ & & & & & \\
\hline & $\begin{array}{l}\text { Wald test, Risk } \\
\text { and Score }\end{array}$ & $p=0.057$ & $p=0.001$ & $p=0.000$ & & & & & \\
\hline & WMW & $p=0.067$ & $p=0.002$ & $p=0.000$ & & & & & \\
\hline
\end{tabular}

Notes: All p-values in Section 3.4 of the paper are robust to controlling only for risk or task score, and neither risk nor task score. 
Table A11: Details about Responders' View of Opponent's Deservingness

\begin{tabular}{|c|c|c|c|c|c|c|c|c|c|}
\hline & & & & \multicolumn{6}{|c|}{ p-values for gender difference } \\
\hline & & Women & Men & Total & t-test & $\begin{array}{l}\text { Wald } \\
\text { test, Risk } \\
\text { Control }\end{array}$ & $\begin{array}{l}\text { Wald } \\
\text { test, } \\
\text { Score } \\
\end{array}$ & $\begin{array}{l}\text { Wald test, } \\
\text { Risk and } \\
\text { Score }\end{array}$ & WMW \\
\hline & Random & 6.21 & 5.94 & 6.06 & $p=0.818$ & $p=0.898$ & $p=0.814$ & $p=0.895$ & $p=0.839$ \\
\hline & Entitlements & 7.64 & 7.09 & 7.45 & $p=0.547$ & $p=0.900$ & $p=0.329$ & $p=0.424$ & $p=0.756$ \\
\hline & Total & 7.08 & 6.39 & 6.78 & $p=0.346$ & $p=0.514$ & $p=0.327$ & $p=0.463$ & $p=0.488$ \\
\hline \multirow{5}{*}{$\begin{array}{l}p \text {-values } \\
\text { for } \\
\text { treatment } \\
\text { effect }\end{array}$} & t-test & $p=0.099$ & $p=0.377$ & $p=0.053$ & & & & & \\
\hline & $\begin{array}{l}\text { Wald test, Risk } \\
\text { Control }\end{array}$ & $p=0.101$ & $p=0.251$ & $p=0.037$ & & & & & \\
\hline & $\begin{array}{l}\text { Wald test, } \\
\text { Score }\end{array}$ & $p=0.123$ & $p=0.401$ & $p=0.058$ & & & & & \\
\hline & $\begin{array}{l}\text { Wald test, Risk } \\
\text { and Score }\end{array}$ & $p=0.098$ & $p=0.303$ & $p=0.041$ & & & & & \\
\hline & WMW & $p=0.095$ & $p=0.473$ & $p=0.076$ & & & & & \\
\hline
\end{tabular}

Notes: As stated in Section 3.4 of the paper, responders' perceived fair allocation to proposers are very similar to proposers' fairness views. All p-values here are robust to controlling only for risk or task score, and neither risk nor task score. 


\begin{tabular}{|c|c|c|c|c|}
\hline & & Women & Men & Total \\
\hline \multirow{7}{*}{ Random } & $\mathrm{N}$ & $\mathrm{N}=30$ & $\mathrm{~N}=32$ & $\mathrm{~N}=62$ \\
\hline & No. of Proposers & $\mathrm{N}=16$ & $\mathrm{~N}=15$ & $\mathrm{~N}=31$ \\
\hline & No. of Responders & $\mathrm{N}=14$ & $\mathrm{~N}=17$ & $\mathrm{~N}=31$ \\
\hline & Age & $20.00(0.30)$ & $20.50(0.32)$ & $20.26(0.22)$ \\
\hline & Task Score & $7.73(0.47)$ & $7.13(0.54)$ & $7.42(0.36)$ \\
\hline & Risk Attitudes & $6.03(0.39)$ & $6.44(0.45)$ & $6.24(0.30)$ \\
\hline & Willingness to Negotiate & $7.80(0.32)$ & $8.28(0.31)$ & $8.04(0.22)$ \\
\hline \multirow{7}{*}{ Entitlement } & $\mathrm{N}$ & $\mathrm{N}=36$ & $\mathrm{~N}=30$ & $\mathrm{~N}=66$ \\
\hline & No. of Proposers & $\mathrm{N}=14$ & $\mathrm{~N}=19$ & $\mathrm{~N}=33$ \\
\hline & No. of Responders & $\mathrm{N}=22$ & $\mathrm{~N}=11$ & $\mathrm{~N}=33$ \\
\hline & Age & $21.11(0.43)$ & $20.40(0.31)$ & $20.79(0.28)$ \\
\hline & Task Score & $8.08(0.47)$ & $7.03(0.46)$ & $7.61(0.33)$ \\
\hline & Risk Attitudes & $6.19(0.34)$ & $7.30(0.44)$ & $6.70(0.28)$ \\
\hline & Willingness to Negotiate & $7.89(0.28)$ & $8.47(0.29)$ & $8.15(0.20)$ \\
\hline \multirow{7}{*}{ Total } & $\mathrm{N}$ & $\mathrm{N}=66$ & $\mathrm{~N}=62$ & $\mathrm{~N}=128$ \\
\hline & No. of Proposers & $\mathrm{N}=30$ & $\mathrm{~N}=34$ & $\mathrm{~N}=64$ \\
\hline & No. of Responders & $\mathrm{N}=36$ & $\mathrm{~N}=28$ & $\mathrm{~N}=64$ \\
\hline & Age & $20.45(0.22)$ & $20.61(0.28)$ & $20.35(0.18)$ \\
\hline & Task Score & $7.92(0.33)$ & $7.08(0.35)$ & $7.52(0.24)$ \\
\hline & Risk Attitudes & $6.12(0.26)$ & $6.85(0.32)$ & $6.48(0.20)$ \\
\hline & Willingness to Negotiate & $7.85(0.21)$ & $8.37(0.21)$ & $8.10(0.15)$ \\
\hline
\end{tabular}

Notes: Standard errors in parentheses. Task score is the math score in the first part of the experiment. Risk is a 1-10 self-assessed index of willingness to take risk with $1=$ "Not at all willing to take risks" and $10=$ "Very willing to take risk". Willingness to negotiate is a 1-10 self-assesed index of overall willingness to negotiate with $1=$ "Not at all willing to negotiate" and 10= "Very willing to negotiate". 


\section{Appendix B: Instructions}

Welcome to the experiment. The experiment is now beginning. Please silence and put away your electronic devices. No communication is allowed during this experiment. If you have questions at any point in this experiment, please raise your hand and an experimenter will come by and answer your question privately.

Please answer the questions on this screen:

Are you a student?

Have you ever participated an ICES experiment before?

Please indicate your gender?

What is your age?

This is an experiment about decision making. You have already earned $\$ 5$ for showing up on time. You may earn more depending on your decision and the decisions made by the other participants. You will be paid privately in cash when the experiment is over. The experiment is conducted anonymously and decisions you make will never be linked to your identity. There are several parts in the experiment and instructions will be given at the beginning of each part.

We will go through the instructions for part 1 now, so please follow.

\section{Part 1 - Math Task}

Random Treatment: We now begin with the first part of the experiment where you can earn money. In this part of the experiment you are asked to solve as many math problems as you can. You have five minutes available. In each problem, you will sum up five two-digit numbers. An example is: $27+18+89+50+17$. In this case the correct answer is 201. For each correct answer, you will receive $\$ 0.25$. At the end of the experiment, you will learn how many of your answers were correct and how much you earned. This will then be paid out in cash together with your other earnings.

In the second part of the experiment, you will be paired with an anonymous person. Each pair will consist of one player A and one player B. Being player A is more advantageous, and on average, player A can earn more money than player B.

Your roles in the second part of the experiment will be determined randomly. The computer will randomly pick player A and B in each pair.

At the end of the experiment, you will learn how many of your answers were correct and how much you earned. This will then be paid out in cash together with your other earnings.

Entitlement treatment: We now begin with the first part of the experiment where you can earn money. In this part of the experiment you are asked to solve as many math problems as you can. You have five minutes available. In each problem, you will sum up five two-digit numbers. An example is: $27+18+89+50+17$. In this case the correct answer is 201. For each correct answer, you will receive $\$ 0.25$. In addition to that, your scores in the math task will determine the roles you will have in the second part of the experiment. 
In the second part of the experiment, you will be paired with an anonymous person. Each pair will consist of one player A and one player B. Being player A is more advantageous, and on average, player A can earn more money than player B.

The number of correct answers you give in the first part will determine your roles in the second part of the experiment. The person who solves most math problems correctly in each pair will earn the right to be player A.

At the end of the experiment, you will learn how many of your answers were correct and how much you earned. This will then be paid out in cash together with your other earnings.

\section{Quiz about part 1}

We will now make sure that everyone has understood the instructions for part 1. Please answer the questions on the screen. If you need help, please raise your hand. When you have finished answering, please press "I understand". If any of your answers are incorrect, the program will tell you so and you get to answer that question again.

1) How much money will you receive for each math problem you solve correctly?

2) If you solve 11 problems, 8 of them correctly, how much money will you receive?

3) If you solve 6 problems, 4 of them correctly, how much money will you receive?

4) If you solve 12 questions, all of them correctly, how much money will you receive?

5) Which player will have an advantageous position in the second part of the experiment?

[Math task is completed]

Random Treatment: It has now been determined how many of your answers were correct. At the end of the experiment, you will learn how many correct answers you gave and the money you earned will be given to you in cash. We now move on to part 2 of the experiment where you can earn more money.

Entitlement Treatment: It has now been determined how many of your answers were correct and who in the pair earned the right to be player A. At the end of the experiment, you will learn how many correct answers you gave and the money you earned will be given to you in cash. We now move on to part 2 of the experiment where you can earn more money.

\section{Part 2-Ultimatum Game}

Random treatment: In this part, you are paired with an anonymous person in this room. You will not be told who that person is either during or after the experiment, and s/he will not be told who you are. Each pair consists of one player A and one player B. We will tell you whether you are player A or player B after we have gone over the instructions. 
Entitlement treatment: In this part, you are paired with an anonymous person in this room. You will not be told who that person is either during or after the experiment, and s/he will not be told who you are. Each pair consists of one player A and one player B. We will tell you whether you have earned the right to be player A or not after we have gone over the instructions.

The experiment is conducted as follows: a sum of $\$ 20$ will be given to player $\mathrm{A}$ in each pair. Player A will then suggest how much of the $\$ 20$ that s/he should keep and how much of the $\$ 20$ should be given to player B. Player B will then decide whether to accept or reject this suggestion. If player $B$ accepts, the $\$ 20$ will be divided as player A suggested. If player $B$ rejects, both players will receive nothing.

Random treatment: Who in the pair ended up being player A or B is randomly determined by the computer. So each person in a pair has an equal chance of being selected as player A or player B.

You will soon learn if you have been picked randomly as player A or not.

Entitlement treatment: Who in the pair ended up being player A or B is determined by your scores from the task you completed in part 1 . The participant who solved more math problems correctly in your pair earned the right to be player A. In case of a tie, the computer randomly selected player A or player B.

You will soon learn if you have earned the right to be player A or not. If you solved more math problems than the other person in your pair, you have earned the right to be player $\mathrm{A}$. If not, you will play the game as player $\mathrm{B}$.

\section{THE GAME}

Once the roles are announced, you will play the game. First, player A will make a suggestion about how to divide the $\$ 20$ between player A and player B. Then player B will decide if $\mathrm{s} /$ he is accepting or rejecting this suggestion. If player B accepts, player A and player B get the amounts player A suggested. If player B rejects, both players get nothing.

Let's look at two examples:

Random treatment: Example 1: Imagine that you are randomly selected to be player $\mathrm{A}$ and are given $\$ 20$ to divide between yourself and player B. You suggest to give $\$ 6$ to player B. Thus you want to keep $\$ 14$ for yourself $(20-6=14)$. Suppose player B has decided to accept any suggestion that gives her/him more than $\$ 5$. Therefore player $\mathrm{B}$ accepts this offer and the $\$ 20$ is split as you suggested. That is, you receive \$14 and player $B$ receives $\$ 6$ from this game.

Entitlement treatment: Example 1: Imagine that you have earned the right to be player A and are given $\$ 20$ to divide between yourself and player B. You suggest to give $\$ 6$ to player B. Thus you want to keep $\$ 14$ for yourself $(20-6=14)$. Suppose player B has decided to accept any suggestions that gives her/him more than $\$ 5$. Therefore player B accepts this offer and the $\$ 20$ is split as you suggested. That is, you receive $\$ 14$ and player $B$ receives $\$ 6$ from this game. 
Example 2: Imagine that you are player B. Your counterpart player A is given $\$ 20$ to divide between himself/herself and you. Player A suggests to give $\$ 5$ to you. Thus s/he wants to keep $\$ 15$ for him/herself (20-5=15). Suppose you have decided that you will accept any suggestion that gives you more than $\$ 7$. Therefore you reject this offer. That is, both of you receive nothing from this game.

\section{Quiz about part 2}

We will now make sure that everyone has understood the instructions for part 2. Please answer the questions on the screen. If you need help, please raise your hand. When you have finished answering, please press "I understand". If any of your answers are incorrect, the program will tell you so and you get to answer that question again.

After everyone has finished answering, we will announce if you are selected as player A in your pair or not.

\section{Random treatment: Quiz question 1)}

There are two people in your pair and 1 person is randomly selected to be player A. What is the chance of you being selected?

Entitlement treatment: Quiz question 1)

If you did not earn the right to be player A, then which player are you going to be?

Random treatment: Quiz question 2)

If you are not randomly selected as player A, then which player are you going to be?

Entitlement treatment: Quiz question 2)

What determines your role in this experiment?

- It is randomly assigned

- It is determined by my math score compared to the other person's score in my pair

Random treatment: Quiz question 3)

Suppose you are randomly selected to be the player A, and you suggest to give $\$ 7$ out of $\$ 20$ to player B. Suppose player B rejects this.

How much does player A receive from this game?

How much does player $\mathrm{B}$ receive from this game?

Entitlement treatment: Quiz question 3)

Suppose you have earned the right to be the player A, and you make an offer of $\$ 7$ out of $\$ 20$ to player B. Suppose player B rejects this.

How much does player A receive from this game?

How much does player B receive from this game?

Random treatment: Quiz question 4)

Suppose the other person in your pair is randomly selected to be player A, and that $\mathrm{s} / \mathrm{he}$ makes you an offer of $\$ 4$. Suppose you accept this. 
How much does player A receive in this game?

How much does player $B$ receive in this game?

Entitlement treatment: Quiz question 4)

Suppose the other person in your pair has earned the right to be player A, and that s/he makes you an offer of $\$ 4$. Suppose you accept this.

How much does player A receive in this game?

How much does player $\mathrm{B}$ receive in this game?

[Announcement of the roles]

Random treatment : On this screen you get to know if you are randomly selected as player A or if you will play the game as player B.

Again, the game is played anonymously. You will never get to learn your counterpart's identity.

As a reminder: First, player A in each pair will make a suggestion to player B on how to split the $\$ 20$. Then, player B will decide to accept or reject this suggestion.

Entitlement treatment: On this screen you get to know if you have earned the role of player A or if you will be player B.

If you solved more math problems than the other person in your pair, you have earned the right to be player A. If not, you will play the game as player B.

Again, the game is played anonymously. You will never get to learn your counterpart's identity.

As a reminder:First, player A in each pair will make a suggestion to player B on how to split the \$20. Then, player B will decide to accept or reject this suggestion.

\section{Ultimatum Game}

For player A:

Random treatment: Congratulations! You were randomly selected as player A. You will now play the game with player B.

Entitlement treatment: Congratulations! You have earned the right to be player A. You will now play the game with player B.

You are now given $\$ 20$. You will make a suggestion on how to divide this $\$ 20$ between yourself and player $\mathrm{B}$.

If player B accepts your suggestion the $\$ 20$ will be split as you suggest. That is player B gets your offer, and you keep \$20 minus the offer.

If player B rejects, you both get zero.

Please state the dollar amount that you want to offer to player B

Please state the dollar amount that you want to keep for yourself

For player B: 
Random treatment: Unfortunately you were not selected as player A. Hence you are player B. You will now play the game with the other person in your pair who is randomly selected to be player A.

Entitlement treatment: Unfortunately you did not earn the right to be player A. Hence you will play the game as player B. You will now play the game with the other person in your pair who has earned the right to be player A.

Player A is now making a suggestion on how to split the $\$ 20$ between two of you.

Before you see player A's actual offer, for every possible suggestion please choose if you accept this or not.

Your payment from this game is going to be determined by the one suggestion that player A actually makes and your choice on whether to accept or reject this suggestion.

If you accept player A's suggestion, the $\$ 20$ will be split as player A suggested. If you reject, then both of you will receive nothing.

Note that this is your final decision. Whatever split player A suggests, your decision here will be used to either accept or reject it.

[Ultimatum Game is played]

The game has been conducted and you will learn the outcome at the end of the experiment, just before your earnings are paid out in cash. We now proceed to part 3, which is the last part of the experiment. Part 3 will consist of several screens.

\section{Part 3- Beliefs}

In this part you will state your beliefs and predictions about your experience and the experience of others in the experiment. You will receive $\$ 2$ for each prediction that is exactly correct. If your estimate is off by one, you will receive $\$ 1$. That means it is in your best interest to guess correctly.

Question 1) (A's only)

When player B decided to accept/reject, s/he saw all possible suggestions from you, not only the suggestion you actually made. Which possible suggestions do you think player B accepted and which suggestions s/he rejected?

If you suggested to keep $\$ 20$ and give $\$ 0$ to player $B$, what do you think s/he chose? If you suggested to keep \$19 and give \$1 to player B, what do you think s/he chose?

$$
\ldots
$$

Question 1) (B's only)

How many dollars do you believe that your counterpart player A suggested that you will get?

How many dollars do you believe that your counterpart player A suggested that s/he will keep? 


\section{Question 2a)}

How many math problems do you think you answered correctly in part 1? (The maximum was 15)

\section{Question 2b)}

How many math problems do you think the people in this room, who participated in the experiment with you, solved correctly on average? (The maximum was 15. Please round up your answer to the closest integer)

\section{Question 3)}

What do you think the gender of the other person in your pair is?

For this question, you will get $\$ 2$ if your answer is exactly correct and \$0 if it is wrong.

[Subjects learn their payoffs]

\section{Questionnaire}

While we prepare your payments, please answer the following questions:

$$
\text { 1) (A’s only) }
$$

On a scale of 1 to 10 , do you feel that you deserved to be player A?

No, I did not deserve it at all

Yes, I definitely deserved it

$$
\text { 2) (B’s only) }
$$

On a scale of 1 to 10, do you feel that the other person in your pair deserved to be player A?

No, s/he did not deserve it at all

Yes, s/he definitely deserved it

3) According to your opinion, what would be a 'fair' distribution of the $\$ 20$ from the perspective of a third party who is not part of the pair?

The fair dollar amount for player A would be:

The fair dollar amount for player B would be:

4) How do you see yourself: Are you generally a person who is fully prepared to take risks or do you try to avoid taking risks?

Not at all willing

Very willing

5) How willing are you to negotiate, in general

Not at all willing

Very willing 
6) Did the random selection of the roles affect how you played in the game in part 2? Yes No

Why or why not?

7) How long ago was your most recent negotiation that you initiated?

8) What did you negotiate about?

9) What is your major?

10) Please specify your ethnicity:

White

Hispanic/Latino

Black/African American

Asian/Pacific Islander

Other

Prefer not to say

11) Was there any part of the experiment that confused you? Please explain.

12) Do you have any other comments? 


\section{Appendix C: Screenshots from the Experiment}

Screenshot 1: Math Task

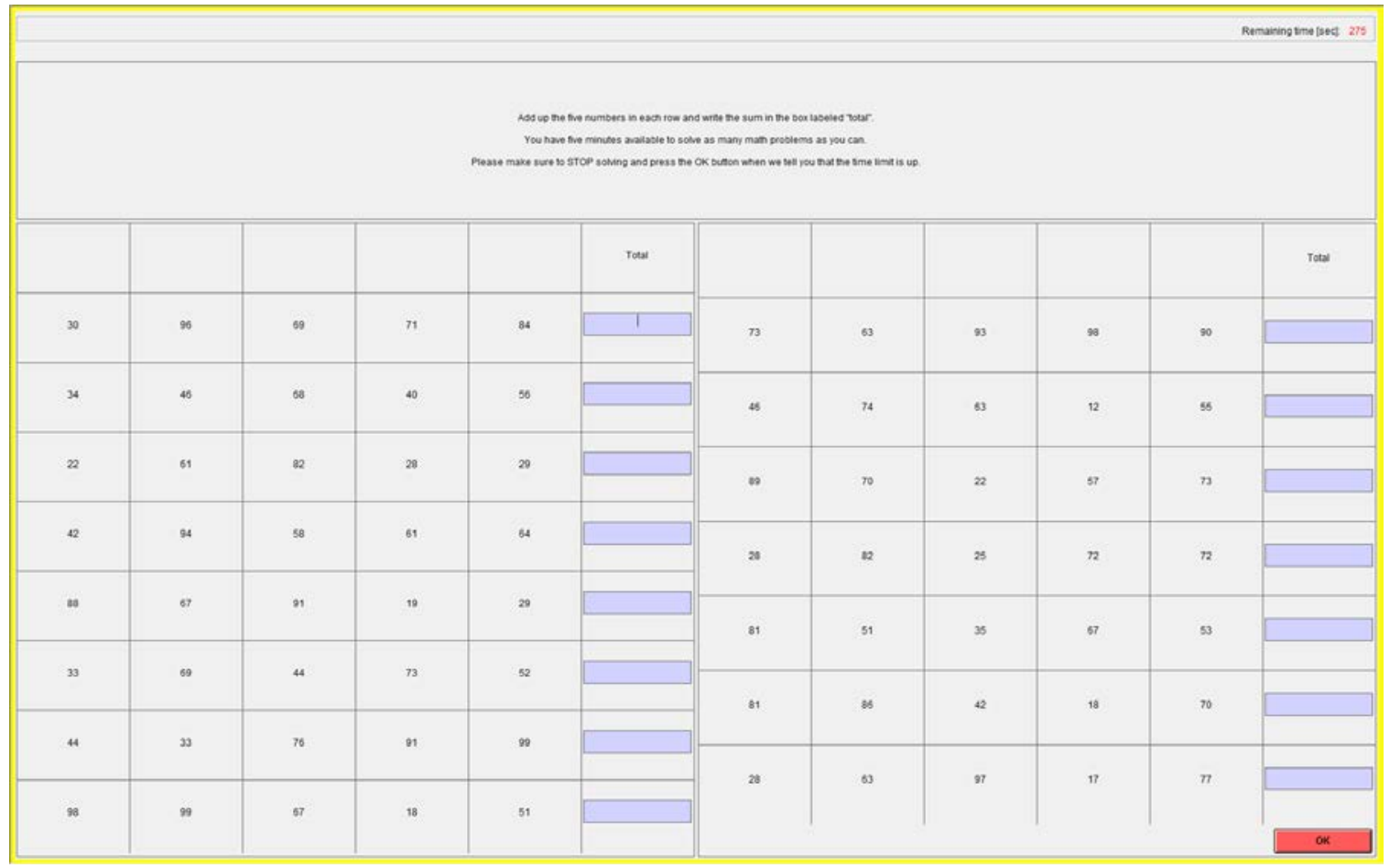

Screenshot 2: Proposer Screen in the Random Treatment

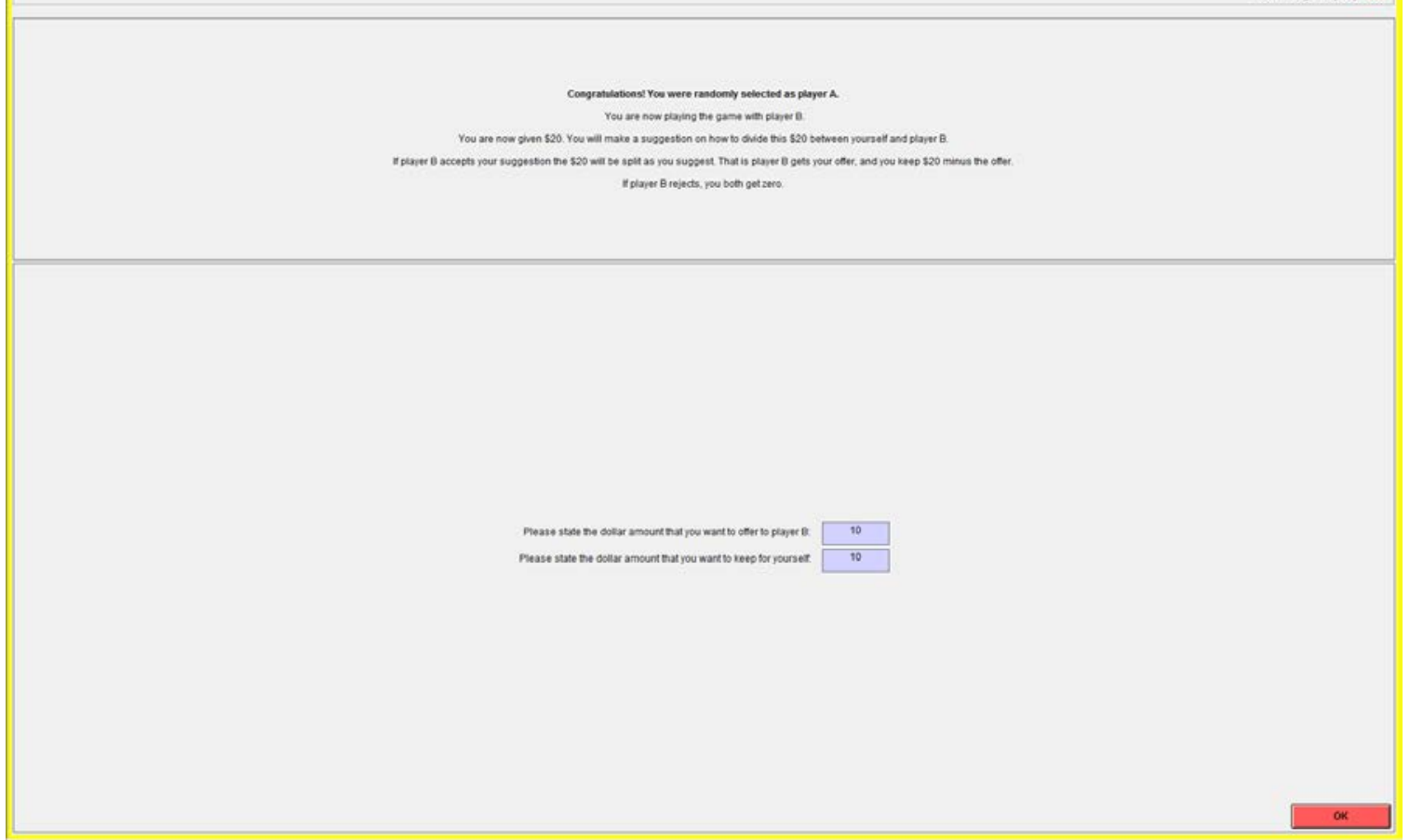


Screenshot 3: Responder Screen in the Random Treatment

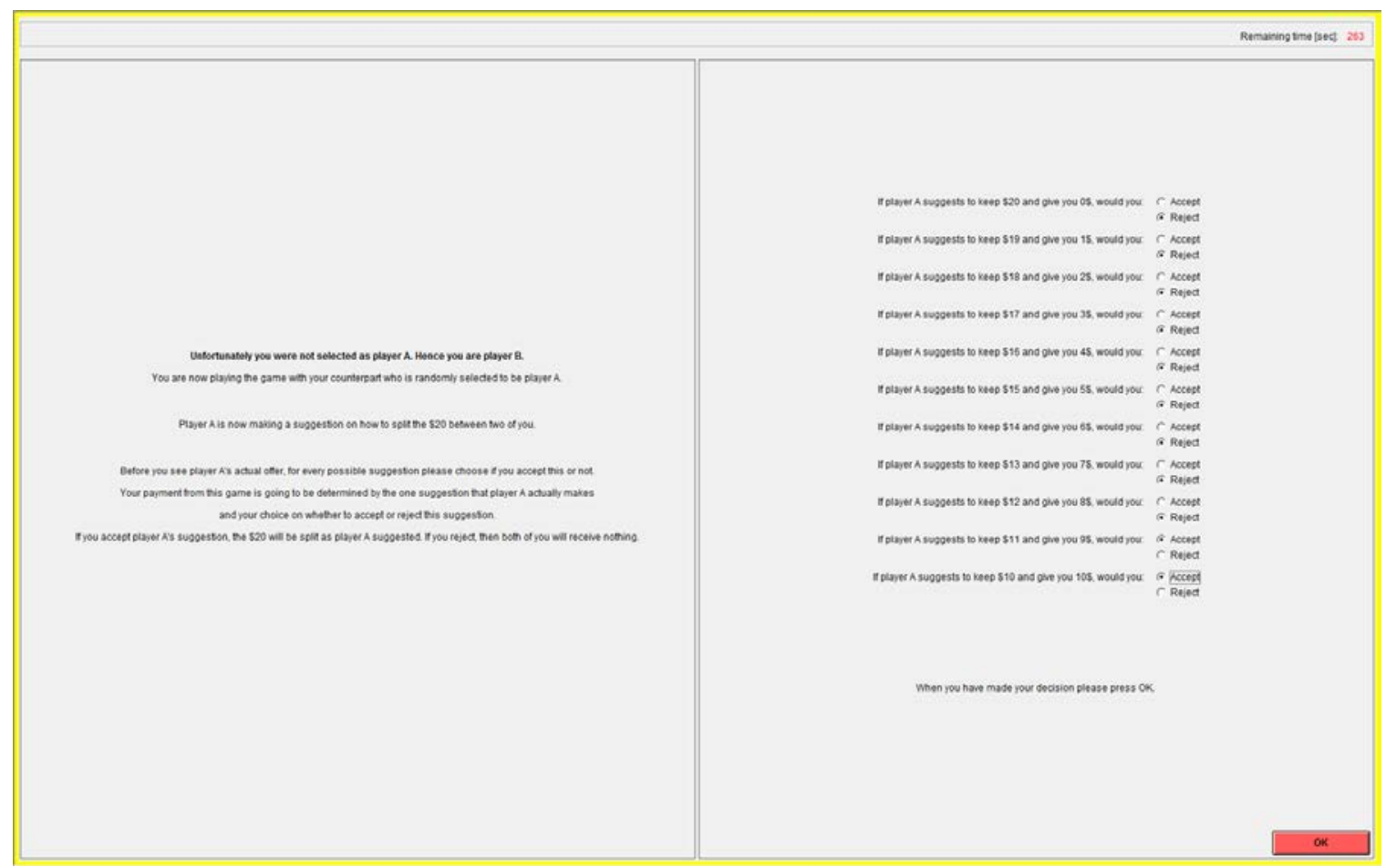

Screenshot 4: Proposer Screen in the Entitlement Treatment

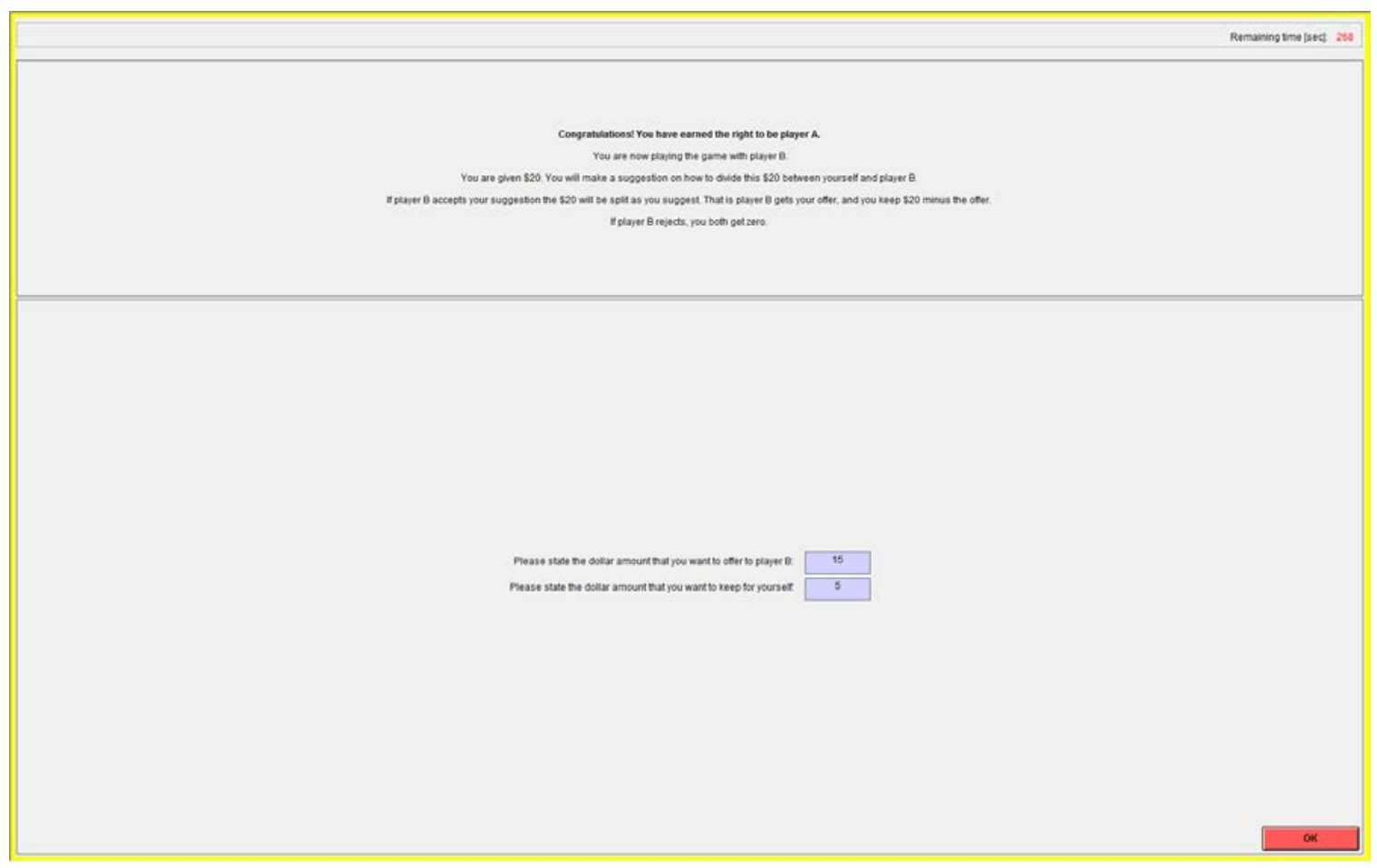


Screenshot 5: Responder Screen in the Entitlement Treatment

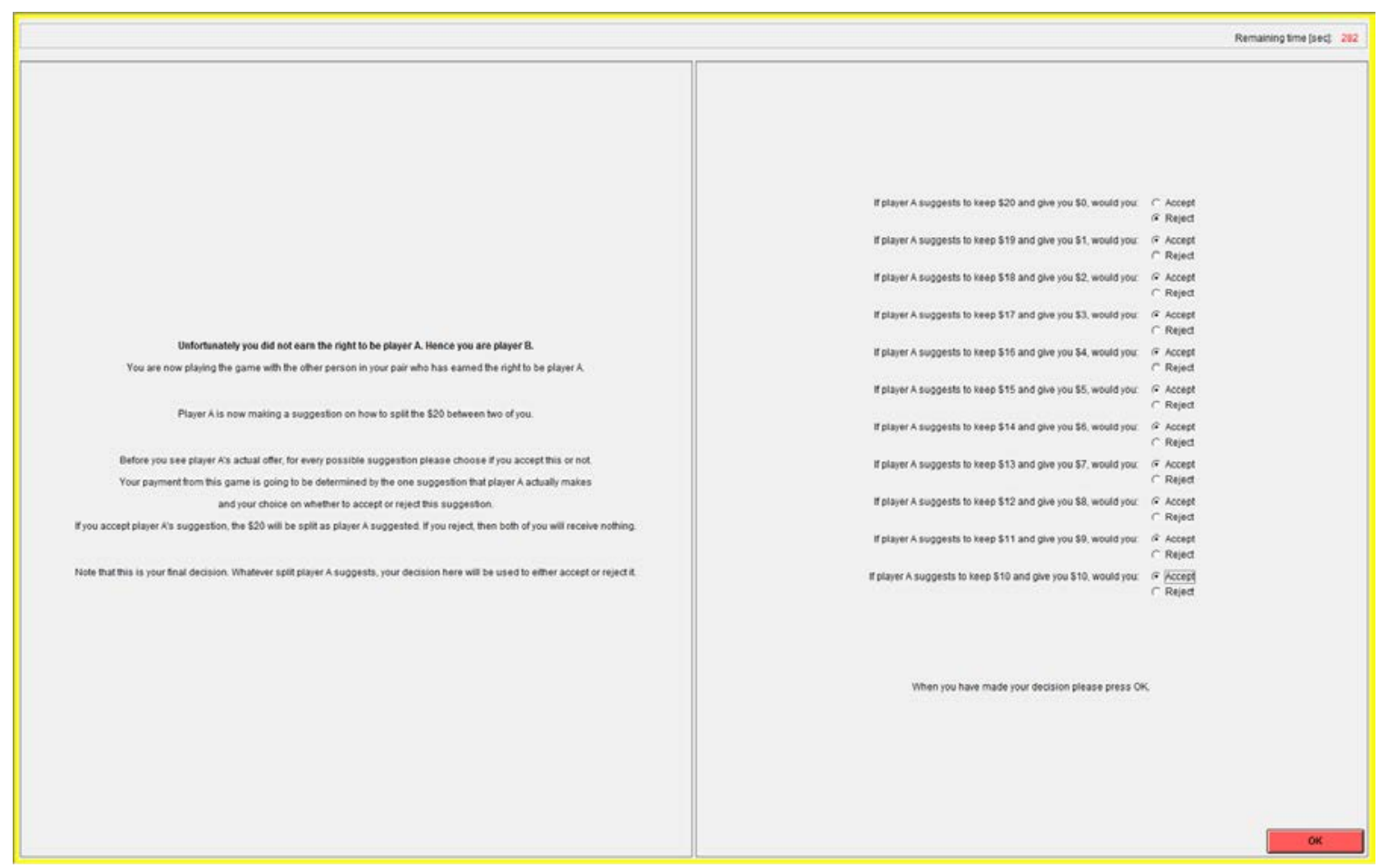

